\title{
The Development of the Missouri Documents Depository System: 1971-1977
}

Byron Stewart

Follow this and additional works at: https://bearworks.missouristate.edu/articles-lib

\section{Recommended Citation}

Stewart, Byron, "The Development of the Missouri Documents Depository System: 1971-1977" (1983). Articles by MSU Libraries Faculty. 115.

https://bearworks.missouristate.edu/articles-lib/115

This article or document was made available through BearWorks, the institutional repository of Missouri State University. The work contained in it may be protected by copyright and require permission of the copyright holder for reuse or redistribution.

For more information, please contact BearWorks@library.missouristate.edu. 
THE DEVELOPMENT OF THE MISSOURI

DOCUMENTS DEPOSITORY SYSTEM:

$1971-1977$

Byron Stewart

A Research Paper Presented

In Partial Fulfillment

of the Requirements for the Degree Master of Arts

Department of Library Science University of Missouri - Columbia December, 1983 
TABLE OF CONTENTS

PREFACE...........................

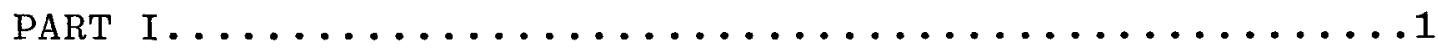

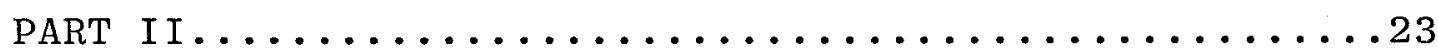

PART III..................................

FOOTNOTES.............................. 53

CHRONOLOGY............................... . . . . . . .

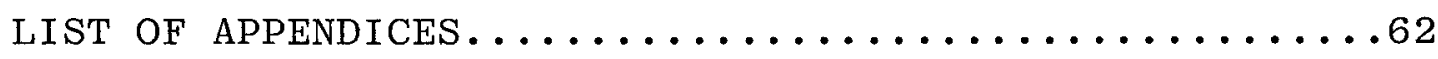

SELECTED BIBLIOGRAPHY .....................118 


\section{PREFACE}

State documents are publications produced, financed, and distributed by state agencies. They range from consumer brochures on auto repair to laws passed by state legislatures. State documents also help to provide accountability for state government. After all, it is taxpayers' money which finances government agencies. Through annual reports, newsletters, and planning documents, an individual can determine the activity--and inactivity--of state agencies.

One large problem exists with this mass of material: nobody can find the information. The distribution of state documents to libraries often depends on being on a state agency's mailing list--a precarious situation at best. Even a change in office secretaries can sever the flow of information from a state agency to the library. The state loses money in producing all these unused documents, and its citizens lose access to information which can be vitally important.

To remedy this situation, many states have set up a system of distributing state documents through a large clearinghouse (e.g., state library) to depository libraries. This system, based in principle on the U.S. government documents depository system, has helped state government and citizens alike in providing a streamlined, efficient flow of information from state agencies through libraries and, ultimately, to the public. 
This paper is a historical account of Missouri's efforts in setting up a state documents depository program. Prior to the 1970s, state documents were underutilized because Missourians either did not know of their existence or could not obtain the documents. This paper spans the time period from 1971 to 1977, in which Missouri went from no depository law to a state depository system that could easily become a model for other states to follow.

It is my hope that this paper will serve as a working tool for those librarians wishing to implement or upgrade their state documents depository programs. The appendices provide examples of primary source documents and other useful reference materials necessary for implementing a successful state documents depository system.

A study of this kind could not have been completed without the help of many fine people. The staff of the Missouri State Library in Jefferson City allowed me access to their files for my research. In particular, Maggie Johnson and Barbara Klempke of the State Documents Division were extremely helpful and courteous during this project.

Meryl Atterberry graciously assisted me by answering my numerous questions and reading the rough draft of this paper. As the mastermind of the Missouri documents depository system, she left orderly files for me to peruse at the State Library, and she encouraged me throughout this project. As a Missourian and as a librarian, I thank Meryl Atterberry for providing Missourians with better access to state government information. 
Sally Schilling, Government Documents librarian at the University of Missouri-Columbia Library, sparked my initial interest in government documents and patiently guided me for four years. For her advice and friendship, I am especially grateful.

My family has provided constant support and encouragement. My friends and chumps listened without turning away from me, and to all of them, I thank you.

My friend and advisor, Aurora Davis, has been more than patient with me and has kept me inspired when despair and procrastination seemed to have the upper hand. For her spirit and guidance, I am thankful.

Finally, to my friend and wife, Elizabeth Bury Stewart-thanks for your car and love. One moved me--but the other sustained me. 


\section{PART I}

Missouri was in trouble. According to the Library of Congress, thirty states already had some type of state documents depository legislation by 1969. ${ }^{1}$ In Missouri, however, there was no system for distributing state publications to its citizens. Furthermore, without a state printer, efforts to obtain state documents meant contacting each agency direct1y for the items. Missouri did have a State Library, but that agency had no statutory authority to collect state documents. This deplorable situation had not gone unnoticed. As early as 1935 , a state planning document appraised the distribution system for Missouri documents:

No one institution is now entrusted with this function. The state documents are distributed by the Secretary of the State, the State Supreme Court Library and by the State Historical Society of Missouri. The services need to be combined. There should be one document center ${ }^{\text {where }}$ all state documents would be assembled. 2

Unfortunately for Missouri and its citizens, no action was taken on this 1935 report until 1971.

In July 1971, Meryl (Wold) Atterberry was hired by the Missouri State Library to be its first government documents librarian. Atterberry later recalled that it was her understanding that she was to develop a state documents depository 
system. In those first several months on the job, however, she worked to improve the federal documents situation at the State Library. Atterberry felt that Missouri was "probably behind many states in its level of consciousness about documents because it had not received leadership from a strong State Library documents department through the years." 3 Seeking to remedy that situation, Atterberry made several contacts with other government documents librarians across the state. She discovered that the Missouri Library Association (MLA) did not have a committee dealing with the unique problems and issues facing government documents librarians. Meryl Atterberry decided this was the place to begin.

Atterberry and a group of public and academic librarians met on October 19, 1972, at the annual MLA Convention in Kansas City. The purpose of this meeting was to coordinate efforts in seeking solutions to the problems of obtaining and using both federal and state documents. This informal gathering decided to seek MLA approval and become a viable committee. At this meeting, Atterberry also met Eddie Altis, Government Documents Librarian at Southwest Missouri State University in Springfield. Both librarians shared a common interest in Missouri state documents, and a partnership was soon to develop.

After this meeting, Atterberry wrote the Missouri Library Association requesting the informal group become a "special committee" on government documents within the MLA. The group was first denied status at the November meeting of 
the MLA Executive Board because of a technicality--the request did not have the needed twenty-five signatures. Two months later, on January 23, 1973, the Missouri Committee on Government Documents finally was approved by the MLA Executive Board--after over thirty signatures were turned in with the request.

Meryl Atterberry and Eddie Altis became joint coordinators of the new Government Documents Committee. One of the five priorities chosen by the Committee was passing a state documents depository law. Atterberry conveyed her thoughts to Altis:

State documents are probably the area where the most work is needed and the most difficult problems need to be solved. . . I feel very strongly that any attempt at a state law should be a very well researched, well-thought out plan, involving strong support from the entire state. To try and fail because we lack the proper support, or to pass a poor 1 aw, would put us in a worse position
than we are now...

There was some hope of introducing a bill in the 1974 session of the Missouri General Assembly, but Atterberry realized that Missouri was well behind in its "level of consciousness" concerning government documents. She even suggested enlisting the aid of Dallas Shaffer to inspire Missouri librarians. Shaffer was Chairperson of the State Documents Task Force of the American Library Association's Government Documents Committee, and she had written an excellent article for the newly-created Government Publications Review detailing the steps leading to Nebraska's new depository 1aw. ${ }^{5}$ 
In September 1973, the Government Documents Committee moved forward. At a September 28, 1973 meeting of the Committee, about thirty librarians discussed a variety of documents topics, including state documents. Meryl Atterberry distributed materials describing elements of state depository legislation, and a State Documents Depository Legislation Subcommittee was established. Ten librarians expressed their desire to help Atterberry with state documents legislation. In addition, the Committee requested Atterberry to seek the help of the MLA Legislative Committee in coordinating their joint efforts for mutual benefit. 6

For almost a year, no formal action took place on state depository legislation. Nevertheless, behind-the-scenes action was vigorous and productive. Meryl Atterberry wrote letters to other states with depository systems, requesting copies of their legislation and other useful ideas or comments. She examined depository laws and regulations in American Library Laws, which dealt specifically with state library laws.

In August 1974, Atterberry completed the rough draft of a state documents depository bill and called a committee meeting. She contacted the volunteers on the State Documents Depository Legislation Subcommittee, as well as other librarians interested in state documents. In her letter, she enclosed a four-page "discussion draft" noting it would be easier for the group to polish a rough draft than to start from scratch. ${ }^{7}$ Furthermore, she attached a "comments" sheet relating to the various sections of her draft which explained 
reasoning on some points and pointed out some potential problem areas.

Atterberry felt four provisions in her draft were "absolutely necessary." These were:

1) clear definitions of terms such as "state publication," and "state agency."

2) requirement that copies of documents be sent to the distribution center automatically, not upon request;

3) sufficient copies to meet the needs of the state;

4) standards for refegrence and loan services for depositories.

Atterberry was also concerned about maintaining a certain degree of flexibility in this proposal, especially in relation to the number of copies an agency must deposit into a depository system, and even the number of libraries participating in such a system. Her concerns about flexibility were justified because the Missouri General Assembly desired detailed, concrete proposals.

Atterberry's concept of two types of depositories, full and partial, was based in part on a suggestion by Trudy Gardner of the University of Missouri Health Care Studies Data Center. Gardner felt many libraries in the state would have no use for all the documents published by the bureaucracy, but "if libraries could request specific areas for collection, then state docs might be used more instead of merely taking up storage space." 9 In other words, partial depositories would build specific subject collections 
of state documents. Atterberry was receptive to this innovative idea, but also wanted the Subcommittee to consider partial depositories in terms of a library receiving some of the more important publications of state agencies.

On September 5, 1974, the State Documents Depository Legislation Subcommittee met for the first time in Jefferson City. Twenty librarians attended this important meeting, later described by Atterberry as "one of the more interesting and productive committee meetings I've ever attended, . . ."10 Several notable events occurred at this meeting. The Subcommittee structure became more formalized. Eddie Altis was chosen chairman of the Subcommittee. Other members were selected to work on various projects.

The Subcommittee decided on several strategic plans for public support. These included: surveying Missouri libraries to show the lack of Missouri documents and their inaccessibility; gathering support from organizations such as the League of Women Voters, Common Cause, and faculty member councils; seeking cooperation from the librarians of Missouri through the Missouri Library Association; and, maintaining a liaison with the MLA Legislative Committee.

The Subcommittee also worked on political strategy. The group decided not to submit its proposal to the Missouri General Assembly for the 1975 session, and instead decided to set 1976 as the target date for the legislation. With extra time, more effective legislative strategy could be formulated. In addition, Meryl Atterberry volunteered to do 
a cost analysis project, gathering data on the current printing and publishing costs of Missouri documents and estimating the costs of a new depository system. A positive cost-benefit analysis could be a key factor in the Legislature's decisionmaking process. In other political actions, the Subcommittee decided to identify document distribution statutes which were currently in Missouri law, but were rarely enforced and should be repealed. Finally, the group decided to examine some probable locations of depositories and estimate the number of documents required for depository distribution.

The bulk of the meeting, however, was spent on Atterberry's "discussion draft." Atterberry had spent a great deal of time preparing this nine-section draft, and the Subcommittee rewarded her efforts. Some changes were made, but none affected the four "absolutely necessary" provisions described earlier. In fact, the Subcommittee strengthened her proposal by adding a definition of the term "depository" library, and changed her request for a "specified" number of documents from an agency to a "sufficient" number of documents. Atterberry had earlier voiced concerns about this later development, stating that "the legislature certainly won't allow a completely open-ended provision as to number of copies:"11 Two other minor provisions were also changed, both expanding the coverage of the depository system. After much discussion, the revised draft was approved. ${ }^{12}$ Finally, the Subcommittee decided to seek a MLA resolution of support and meet again in approximately six months. ${ }^{13}$ 
It was not coincidental that the Missouri Library Association's Annual Conference convened only two weeks after the initial Subcommittee meeting. With the librarians freshly aware of the need for depository legislation, the Subcommittee prepared a handout detailing its concerns for a state documents depository system and stressing an idea which would become the main theme of this campaign: the citizen's right of full access to information. On September 20, 1974, the Missouri Library Association passed a state documents resolution strongly supporting legislation to establish a depository library system for Missouri state publications. ${ }^{14}$ In addition, the resolution gave the State Documents Depository Legislation Subcommittee authorization to "continue preparation of a bill," and power "to work with the Legislative Committee of the Missouri Library Association to gain legislative support, and to work to gain support of citizens throughout Missouri."15 The emphasis of the bill was on the citizens, not the librarians, of Missouri. This was to be a key tactical point in the legislative battle.

Thus, by October 1974, a bill had been drafted, and Missouri librarians had endorsed the state documents depository plan. Nevertheless, much work remained to be done. The Subcommittee reported its efforts and goals to the Legislative Committee of MLA at its meeting in October 1974. The Legislative Committee "promised to help and support the committee in getting the legislation passed."16 The Subcommittee realized the important liaison it should maintain with the 
Legislative Committee. In fact, one year earlier, the full Government Documents Committee of MLA voted to request the cooperation of the MLA Legislative Committee in promoting the state depository legislation. Only time would tell the effectiveness of the MLA Legislative Committee.

The Subcommittee drew up a state documents questionnaire in October to determine the availability of Missouri documents in Missouri 1ibraries, as well as the need for such documents. ${ }^{17}$ There was a general lack of information among the Subcommittee members as to the types of Missouri documents that libraries were receiving. Furthermore, by sending such a questionnaire, the group hoped that support could be demonstrated for the depository system. Unfortunately, the questionnaire proved to be a dismal failure.

The questionnaire was distributed in January 1975 to about 130 Missouri libraries. Only fifty-eight libraries (45\%) responded to the two-page questionnaire. Twenty-seven college or university 1ibraries responded, but on1y twentyeight public libraries answered the questionnaire. ${ }^{18}$ The results were disappointing and showed, indeed, that "many Missouri libraries seem to have very little use of and, therefore, need for Missouri Government publications."19 Some of the results of the questionnaire were quite revealing:

1) The staffs of forty-nine libraries spent only $0-5$ hours per month obtaining and processing Missouri documents.

2) The staffs of nineteen libraries said they had $\underline{0}$ requests per month for Missouri documents. Another thirteen had only $1-5$ requests monthly. 
3) To the question: "Are your needs for Missouri state government publications being met by the present distribution system," the response was 26--yes, 19--no.

4) To the question: "Are you able to obtain the information you need about Missouri state government operations and services," the response was 37 --yes, 10 --no. 20

Obviously, the Subcommittee had not obtained a mandate for a depository system from this questionnaire. Indeed, the results seemed to indicate that most libraries were having few difficulties with the status quo, namely few Missouri documents and even fewer requests. Subcommittee members were not disheartened, however. They felt that a depository law would improve the access, which, in turn, would improve the requests for state documents.

After the questionnaire was distributed, Eddie Altis, Chairman of the State Documents Subcommittee, announced a second meeting on the subject of the state depository system. On February 28, 1975, the second Subcommittee meeting was held in Jefferson City. The purpose of the meeting, according to Altis, was to "try to tie this all up into a very attractive package none could refuse." 21

The meeting began with a series of committee reports. The Library Data Committee reported on the questionnaire results, discussed earlier. Meryl Atterberry had worked on the cost analysis problem for the Subcommittee, and she reported that most of the administrative procedures required to activate the depository program were already in place at the Missouri State Library. Only one clerical person would 
be added to the staff. The State Library would absorb the following expenses in its budget:

1) salary of depository librarian.

2) publication and distribution costs of month1y state documents checklist--already being published.

3) operations costs such as travel, office supplies, and telephone. ${ }^{22}$

Atterberry estimated the added costs in personnel, equipment, materials, and postage at approximately $\$ 6,500$. The figure of $\$ 10,000$ was cited, however, at the Subcommittee meeting as a workable figure. Still, the Subcommittee was most impressed at the minimal costs for such a service.

Other committees discussed the need for continued publicity and urged organizational support, as well as support from civic groups. The emphasis would remain on the citizens--and their right to accountability in state government. Also, the existing, though out-dated laws in the Missouri Revised Statutes were discussed because some sections would be affected by the depository legislation.

The Subcommittee also examined the text of the revised draft from its first meeting. Only one major change was made. This was in section 5 of the draft pertaining to the number and location of depositories. The Subcommittee decided to include each state university library system as a depository, if that institution so desired. The librarian representing Northwest Missouri State University at Maryville provided the impetus for this decision. That University's inability to 
obtain a Federal depository designation under the current law limiting such designations made its library administration determined that the situation not be repeated at the state level. Furthermore, the Subcommittee decided to set no limit on the number of depositories. Flexibility was still the working concept in the number of depositories and their locations. 23

Finally, the Subcommittee made some tactical decisions. Members decided that Summer 1975 would be the latest time for presentation of the proposed depository legislation to the Coordinating Board for Higher Education. The Coordinating Board would have to approve such a plan as it had administrative authority over the State Library. Without the Board's support, there would be little hope of Governor Bond's endorsement or passage in the General Assembly. The Subcommittee decided to expand its publicity efforts with a promotional leaflet and a MLA booth at the next annual conference. Also, the group discussed the topic of legislative sponsorship of the bill and quickly realized how much there was to learn concerning the politics of legislation.

Al1 in all, this February meeting was described as "very productive." 24 The next steps were two-fold: 1) increased promotional awareness, which all the librarians could participate in; and 2) the bill itself, including the final drafting, the fiscal note, and the Coordinating Board endorsement. This later step would involve three key people: Eddie Altis, Meryl Atterberry, and Betty Schramm, Branch Supervisor at St. Louis County Library. 
The period from March to July 1975 was one of primarily behind-the-scenes activity. Public awareness of the proposed depository legislation became the main theme. The librarians on the Subcommittee contacted other librarians in their areas, as well as various civic organizations. In some cases, support was lacking. The League of Women Voters withheld official endorsement because its legislative program had been set so far in advance, but individual League members supported the legislation as private citizens. ${ }^{25}$ Meryl Atterberry wrote an informative essay in March, entitled "A State Documents Depository Law for Missouri," in which she detailed the current state publications' situation in Missouri and outlined the solution, the legislation, and cost. In later reprints, Atterberry did not always sign her name to this document. Perhaps her reasoning for this was best summed up in a letter she wrote to Eddie Altis:

I'm not just being shy when I say that I think you [Altis] should be more prominent than $I$. Though our motives are pure at the State Library, we can always be accused of "empire-building" in trying to add a program. It looks much better to have the push come from out in the state than from here. 26

Atterberry later stated a similar feeling to another librarian:

The Missouri State Library did not feel it appropriate to be directly involved in lobbying, so all my coordinating efforts were "behind the scenes." Anyway, support from legislators' constituents is far more effective than state agency arguments. 27 
Another large project Atterberry was working on in early 1975 was a more detailed cost analysis. The Missouri Legislature would certainly be interested in a cost-benefit analysis for depository legislation. Would it not cost the State more money to print additional copies of a state publication? What about added personnel costs? New equipment? As stated earlier, Atterberry estimated the depository program would cost approximately $\$ 6,500$, with only one clerk added to the payroll. Yet, what about these other costs?

Atterberry needed to estimate how much the depository system would cost the state in printing additional copies of publications. There were problems, however. Missouri had no state printer, so each agency had to do its own printing or contract for such services. An agency report cited the legal necessity for many publications, stating: ". . there are ninety-eight constitutional or statutory provisions which require reports of various kinds." 28 These reports were mostly in the form of state agencies' annual or biennial reports. Atterberry realized that an extensive survey of state agencies would be required to determine how much each agency was spending in printing costs. The Accounting Division, however, informed her that publication costs were not separated in agency budgets from other "operational" costs. Atterberry learned that many state publications were printed in such large quantities that the forty-five to fifty copies suggested for the state depository system would not result in added printing costs, but would provide a more "efficient 
use of copies already produced." As Atterberry noted, "printing costs diminish after a certain point, so cost per copy would be low even in cases where additional copies would have to be run for the depository system."29

Nevertheless, Atterberry realized the Missouri Legislature would want some concrete figures. She learned that librarians in Iowa had experienced a similar dilemma in proposing depository legislation in 1974. Iowa, however, had a state printer, and cost information was available. Thus, Iowa librarians prepared a detailed analysis of costs for additional printed copies, and came up with this conclusion: the total estimated cost for all agencies of seventy-five added copies of each publication was $\$ 3,910.30$ Obviously, even this low figure overstated the actual cost, because in reality, requesting another fifty copies of a publication would often not require "added" printing--as most publications were mass-produced anyway. In Atterberry's judgment, the depository system would be a much more efficient method of disseminating the information to the public. As she put it, "Since the system would automatically place publications in library collections, easily available to the public, agencies could print in lesser quantities and still be assured of wide exposure." 31

Atterberry continued working on a precise cost estimate. In June 1975, after much discussion with other state officials, Atterberry calculated a Fiscal Year $1975-76$ budget ( $10 \frac{7}{2}$ months) between $\$ 8,400-\$ 9,000$, still under the $\$ 10,000$ figure. 
This satisfied Chairman Eddie Altis, who responded:

I am pleased with the cost as long as it can be honestly contended it will be below $\$ 10,000$. Of course, I think it would be worth three or four times that much, but others might not. 32

However, this cost figure would soon rise dramatically.

The State Documents Depository Legislation Subcommittee held a third meeting in Springfield on July 18, 1975. This meeting, while productive, was not as significant as the previous two meetings. For one reason, only a small group of librarians was present. The meeting was divided into three subjects: publicity, the cost analysis, and strategy. Concerning publicity, the group agreed to set up an information table at the October conference of MLA. Members discussed ideas concerning posters, buttons, and brochures. Also, the Subcommittee chose a time for an open meeting to be held at the MLA Conference, at which the proposed Missouri depository legislation would be discussed. The Subcommittee further examined the need for better coordination and cooperation among librarians in their efforts. One member agreed to draw up a list of news publications from professional organizations in an effort to get publicity to create an awareness among other people.

The major action in this meeting occurred with an adjustment of the cost estimate. Betty Schramm proposed, and the Subcommittee passed unanimously, that a half-time professional cataloger be added to the cost estimate. This person would provide for descriptive cataloging of the 
documents, thus performing a valuable service to those depositories receiving Missouri documents. The increase in costs would still keep the total cost "less than $\$ 15,000$ at the maximum."33 Some Subcommittee members felt an apparent "cost backlash" was taking place. They had heard that if the cost analysis was too low, the significance of the bill would also be diminished.

In terms of the revised draft, no substantive changes were made from the previous February 28 meeting. Standards for the depositories were mentioned, but nothing was added to the proposal. The Subcommittee discussed political strategy with renewed vigor. Several names were mentioned as possible sponsors, including Representatives Gary Rust (Cape Girardeau), Harold Reisch (Columbia), Richard Rabbitt (St. Louis), Joe Holt (Fulton), and Larry Mead (Columbia). Senators Larry Marshall (Columbia), Paul Bradshaw (Springfield), William Cason (Clinton), and A. Clifford Jones (St. Louis) were also named as potential sponsors. No one, however, was chosen to sponsor the bill at this meeting. The meeting notes adequately described the feeling: "Our hope is to keep the legislation from becoming a political pawn of any sort, and to get the sponsorship of those who will be able to carry it through." Finally, the Subcommittee decided on a tentative "calendar for action," as follows:

$\underline{1975}$

August 1 Survey of interest in becoming a depository library 
1975

August $31 \quad$ Newsletter listing with mailing of background information to Coordinating Board members

September 12 Meeting with Coordinating Board for Higher Education

September 30 Prospective sponsor(s) for legislation in General Assembly chosen

October 1 Have initial copy of brochure ready to print

October 22-24 MLA Convention; information desk; Documents Committee open meeting

November 1 Begin letter-writing campaign to legislators

December $1 \quad$ Prefiling of depository bill $\underline{1976}$ January-April DO IT! 34

With its attack plan finalized, the Subcommittee adjourned. Mery1 Atterberry described the mood of the members as follows: "The general feeling of the Committee toward passage of the bill is optimism, but coupled with a realistic understanding of the pitfalls which can befall a bill in the Missouri Genera1 Assemb1y."35

The pace quickened as the legislative session drew near. The first order of business was a survey of libraries to see which were interested in becoming depository libraries. Meryl Atterberry and Eddie Altis collaborated on a letter which was sent to both public and academic libraries and which served a two-fold purpose: 1) it provided a survey of how many $1 i-$ braries were interested in depository status; and 2) it served 
as a useful informational brochure on the need for depository legislation. Concerning the first point, the Subcommittee needed to have a good idea of just how many libraries were interested in becoming state documents depositories. This would be an important point in the legislative hearings, yet the Subcommittee hoped to retain some flexibility, too. The letter-survey emphasized that "indicating interest does not assure that a library can become a depository." That ultimate decision could either be included in the depository law or be left to the discretion of the State Library. The actual survey, only one page long, was quite direct in its questions and could be completed in several minutes. Those libraries "definitely not interested" in depository status were told not to return the survey sheet. In light of its previous disastrous questionnaire, the Subcommittee certainly must have waited with eager anticipation for this survey's results.

Meryl Atterberry described the survey's results as "very useful." They were as follows: 36

Definitely interested--full depository...7 libraries Definitely interested--partial deposit...6 libraries Would be willing to serve geographical

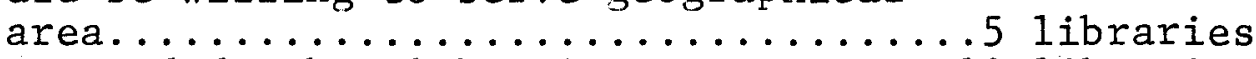
Recommended other libraries...........10 libraries Not interested (not all sent in)......13 libraries

One library replied, "We would like to be a regional depository but we could do this only if we were reimbursed for staff time and expenses such as shelving." This was unacceptable to the State Library, for it was up to the individual depositories 
to maintain their own collections. An even more humorous "not interested" came from a library which had been a United States Government depository since 1874. That library responded that it was "attempting to get out of that business" of collecting government documents! ${ }^{37}$ Nevertheless, the Subcommittee was pleased with the responses, for it now had some idea as to the number of libraries interested in depository status.

Al1 was not good, however. Cost estimates continued to mount. The addition of a half-time professional cataloger was estimated at $\$ 5,136$ for Fiscal Year 1976-77, and postage also increased substantially in Atterberry's estimates, after she confessed to Altis of finding an error in the original postage calculations. Furthermore, Atterberry now estimated fifty to sixty libraries, instead of the forty to sixty used in her June estimates. Atterberry's new August figures showed a total allocation of between $\$ 16,400$ and $\$ 17,400$ (postage rates varies) for the FY 1976-77 budget. ${ }^{38}$ The costs were still under $\$ 20,000$, and the Subcommittee consensus was to keep it under that figure. After a11, Nebraska requested over $\$ 45,000$ for its first full year of state documents depository operations, so Subcommittee members still felt they had a great bargain to offer to the Missouri Legislature. In early September, the Subcommittee prepared to meet with the Coordinating Board for Higher Education. Board members were mailed background information, and some librarians made personal contacts with individual members. The Subcommittee 
was uncertain if its request would even be included on the agenda, but the members realized the political significance of having the Coordinating Board's endorsement of their plans. On September 12, 1975, three members of the Subcommittee, Eddie Altis, Betty Schramm, and Meryl Atterberry attended the Board meeting at Maryville, and presented the case for depository legislation. The Board heard their views and approved the plans by unanimous vote. With its first political action a success, the Subcommittee renewed its efforts.

Depository legislation still needed a sponsor. At the July 18 meeting, several names had been discussed as possible sponsors but no one was selected. Betty Schramm, who was also a member of the MLA Legislative Committee, volunteered to ask her brother-in-law, Jack Schramm, a former state legislator, for his ideas. In August, Jack Schramm offered this advice to his sister-in-1aw: get as many sponsors as possible, with one main sponsor in each house; introduce the bill in both houses, but have a Democrat (majority party) sponsor the bill in the House. Schramm offered to give advice on certain "cliques" in the Legislature, but warned the Subcommittee "not to depend on anyone."39 Jack Schramm did help the Subcommittee secure a Democratic sponsor in the House, Rep. P. Wayne Goode (Normandy), and as Atterberry later commented, Jack Schramm proved to be "a valuable source of advice throughout the session. $" 40$

The Subcommittee continued to solicit publicity for the legislation. The Missouri Association of Social Workers 
published an editorial supporting the state depository system in its newsletter, Citizen's Voice. Meryl Atterberry had an earlier article describing the proposed legislation reprinted in FOCUS/Midwest. ${ }^{41}$ The Missouri Political Science Association passed a resolution supporting the efforts of the Missouri Library Association. Perhaps the Subcommittee's biggest endorsement came on October 29, 1975, when Governor Christopher (Kit) Bond announced his support for the depository legislation. The Governor's endorsement followed a meeting between Atterberry and two of Bond's staff members. Secretary of State James C. Kirkpatrick also endorsed the depository bill saying, "We think the bill an excellent idea - one which will insure public access to state documents." 42 This, too, was an important endorsement because the Secretary of State had statutory authority over the State Archives, which collected state publications.

The theme "State Docs '76," characterized the Subcomittee's final publicity drive at the annual MLA Conference held October 22-24, 1975. At this Conference, an information table was set up with brochures and exhibits, and there was an openmeeting presentation to over forty librarians concerning the merits and status of the proposed depository legislation. With prefiling of bills only a little more than a month away, Martha Maxwe11, Director of the Cape Girardeau Public Library, secured over twenty librarians in the state to coordinate lobbying efforts in their areas. The background work was over. The focus of Missouri librarians shifted toward the Missouri Legislature. 
With its background work completed, the MLA Subcommittee on State Documents Depository Legislation awaited the convening of the 1976 session of the Missouri General Assembly. On December 1, 1975, Rep. Wayne Goode prefiled House Bill No. 1172 (HB 1172), an act "to establish and maintain a depository library system for publications of Missouri state agencies."43 Bills were prefiled a month in advance of the session as an organizational and time-saving device. Subcommittee members realized their bill had only a slim chance of passage. This was the "short" session (January-April) of the General Assembly, six weeks shorter than the odd-year session. Also, the Speaker of the House, Richard J. Rabbitt (St. Louis), reportedly announced that he wanted on 1 y $20 \%$ of the bills reported out of committees with a "DO PASS" recommendation. Sensing the dangers lying ahead, Chairman Eddie Altis of the Subcommittee wrote his fellow members a memo on December 23, 1975, posing some of the obvious questions (e.g., cost, depository designations) and offering some basic answers. He urged his colleagues to write, phone, or visit with their representatives and senators. As he indicated, ". . . this is the short session of the General Assembly and we are in serious danger of being 
buried under an avalanche!"44

Betty Schramm, acting in her capacity as Coordinator of the MLA Government Documents Committee, sent a letter to directors of Missouri libraries in January 1976, asking them to contact their representatives and senators. Furthermore, she enclosed a list of twenty-nine area coordinators, each of whom was assigned certain counties to help coordinate publicity efforts. ${ }^{45}$ Missouri librarians were quietly becoming political lobbyists.

On January 7, 1976, the Second Regular Session of the 78th Missouri General Assembly opened in Jefferson City. Governor Bond presented his annual message to legislators but with no mention of HB 1172, the state documents depository bill. This was no surprise due to the noncontroversial nature of the bill. HB 1172 was formally introduced by Rep. Wayne Goode on the first day, and six days later, it was referred to the Committee on Governmental Organization. This was the first obstacle for librarians. Subcommittee members had hoped that $H B 1172$ would be referred to the House Committee on Education, chaired by their sponsor, Representative Goode. Instead, the bill was referred to the Governmental Organization Committee, chaired by Rep. Alex Fazzino (Kansas City). Representative Fazzino, who had no particular interest in libraries, might have kept the bill buried in his committee, but he was paid a friendly phone call by former legislator Jack Schramm, and a hearing was promptly scheduled for January 26. 
Unfortunately for the librarians, HB 1172's sponsor, Rep. Wayne Goode, failed to show up on January 26 for the hearing on his bill: To avert a near disaster, a colleague of Goode's, Rep. Steve Vossmeyer (St. Louis), volunteered to officially present the bill. Next, Betty Schramm voiced the arguments for the depository legislation. No opposition was expressed by the legislators at the hearing, much to the relief of the fourteen librarians present. Atterberry described the hearing as "encouraging" and further wrote in an "urgent memo": "Now is the time to inundate all committee members with letters requesting a speedy 'DO PASS' recommendation."46 However, a speedy "DO PASS" did not occur. Librarians waited--and waited. Even Fazzino's home territory urged the passage of HB 1172. Under the persuasion of Dorothy Arneson, Documents Librarian at Kansas City Public Library, the Jackson County Legislature passed a resolution on February 2 , by an 8-0 vote, which read in part that the County Legislature "does hereby declare its support of House Bill No. 1172 and urges the Government Committee of the House to favorably report the bill to the House. . ."47 After more than three weeks had elapsed since the hearing, Fazzino's committee finally reported the bill out with a "DO PASS" and placed it on the Consent Calendar in the House. Atterberry later heard that the long delay was a form of "punishment" for their sponsor being absent at the hearing:

There was good news, however. "Noncontroversial" bills were placed on the Consent Calendar, where they remained for 
five working days only. If there were no adverse comments or challenges, the bill would automatically be "perfected" and come up for a vote of the full House. Thus, bills placed on the Consent Calendar were acted upon much quicker than those on the regular House Calendar. HB 1172 survived its five-day stay without mishap, and librarians again breathed a sigh of relief. Thus, the bill was perfected February 25, and final passage in the House appeared imminent. 48

The success of the MLA Subcommittee was due to several factors. The librarians were vigorously campaigning for $\mathrm{HB}$ 1172. They were writing letters to their representatives and making their presence felt at the General Assembly. Also, they had a good bill and were selling it well. Even Representative Goode described the fiscal note budget as a "relatively modest $\$ 18,605$ for the first full year of operation." 49 Furthermore, the librarians reiterated the cost savings to the fiscally-conservative Legislature. Librarians noted that massive wastes in time, paper and effort could be reduced through an efficient distribution system which assured that the publications would be available to the public across Missouri. Even postage costs could be cut, argued the State Library, because it would be shipping bulk mailings at lower postal rates available only to libraries.

On March 9, 1976, the House passed HB 1172 by a vote of 129-0. To add to the delight of the Subcommittee, not one word had been changed from the original bill. Meryl Atterberry asked her colleagues to thank their representatives 
("a step often overlooked. . . .") and urged them to begin contacts with their senators. As she put it, "It's generally tougher to pass bills in the Senate, but, on the other hand, more people can zero in on each Senator, since there are only $34 . " 50$

On March 10, one day after House passage, HB 1172 was read in the Senate for the first time. Sen. William J. Cason (C1inton), the Senate President Pro Tem who had earlier described HB 1172 as an "excellent idea," acted to speed the bill on its passage. On March 17, Cason assigned the bill to the Senate Committee on State Departments, chaired by Sen. William B. Waters (Liberty). Waters announced a hearing for March 23.

The March 23 hearing began with no surprises, as Representative Goode formally presented HB 1172 to the Senate Committee. Next, MLA Subcommittee Chairman Eddie Altis testified in favor of the bill, explaining its various provisions to the senators. The hearing was described by Betty Schramm as "favorable," but she noted: "We have no special support in the Senate as we did in the House. . ." 51 Indeed, she was quite right. After the hearing, the Senate Committee pressed Representative Goode to come up with a shorter substitute. Goode informed Meryl Atterberry and Betty Schramm of the deteriorating situation, and they drew up a substitute bill, reducing the original length by about onethird. However, it was too little and too late. The next day, April 7, a Senate Committee Substitute for HB 1172, drawn 
up by the Senate Committee, was reported out of the State Departments Committee with a "DO PASS" recommendation. 52

The MLA Subcommittee was shocked. HB 1172 had been stripped of $80 \%$ of its contents (from 106 lines to a mere 21 ). Furthermore, the crux of the legislation, namely the statutory power to collect state agency publications, was omitted. True, the substitute retained the power of the State Library to distribute publications to designated depositories; however, it did not give the State Library any legal authority to acquire the necessary publications. Therefore, the status quo would be retained--no system for obtaining state publications. The Senate Committee even changed the Act's original title to this misleading title: "To provide for distribution of publications of Missouri state agencies."

What had happened to HB 1172? Meeting in executive session, the Senate Committee had expressed some serious, if petty, concerns about the original bill. First, some senators were worried about all that "junk" filling up libraries. Yet, as Betty Schramm pointed out, "If state agencies are producing 'junk' shouldn't the public have the opportunity to see it and hold them accountable?"53 Second, Chairman Waters wanted the bill cut length because he thought bills should be kept short. Third, some senators questioned the concept of depository status, and worried that not "all" libraries would want to be depositories. The original bill, however, never specified that "all" 1ibraries would be depositories. In fact, the great majority of libraries in Missouri did not want to be 
depositories. Fourth, some members questioned sending Missouri documents to the Library of Congress and an "additional national research library," so that provision was cut. Fifth, some members worried about a new bureaucratic position being created in each state agency to carry out the job of supplying that agency's documents to the depository center. Finally, the revised fiscal note pushed the cost to over $\$ 20,000$ ( $\$ 20,052$ to be exact) for Fiscal Year 1977-78, the first full year of operation.

Meryl Atterberry and Betty Schramm realized the gravity of the situation. The session would be over in three weeks, and they now had only a skeleton substitute--with no clout-for HB 1172. They went back to their drawing boards. Two provisions were necessary. First, and most important, was the requirement that state agencies must deposit their publications with the State Library--and in "sufficient" quantities. They wrote:

Every state agency, as enumerated in Section 2, shall upon release, deposit with the State Library sufficient copies of each of its publications to meet the purposes of this act. 54

This was crucial to the legislation because, as Atterberry stated, "without such a provision, the bill was useless."55 The second amendment Atterberry and Schramm drew up was a definition of "state publications." They recognized that the effectiveness of the law could be undercut if a particular agency decided its documents were not "true" state publications. Also, other states with similar laws included 
such a definition. They proposed the following amendment:

Section 1. As used in this act, "state publications" shall include all multiply-produced publications of state agencies, regardless of format or purpose, with the exception of correspondence and interoffice memoranda. 56

Atterberry and Schramm realized their only hopes lay in getting these amendments added to the bill when it reached the floor of the Senate. The bill's original sponsor, Representative Goode, felt the additions were reasonable. But, HB 1172 was out of his hands, for all practical purposes. The MLA Subcommittee needed the support of the Senate--and soon. Betty Schramm, in her memo to depository bill coordinators on April 14, 1976, pointed out the necessity for writing the senators on the Committee, thanking them for voting the bill out with a "DO PASS," but asking them to add the two key amendments. Describing the Committee's elimination of these important provisions as "not intentional," Schramm diplomatically refused to criticize the Senate: "We can be genuinely effusive in our thanks - the bill could easily have died of neglect in committee!" But, as she noted, time was crucial--only eight working days remained in the session, and, as she wrote, "Now is the time to pull out all the stops!" 57 Time had all but nullified any chance of getting HB 1172 passed. The Senate Committee had kept the bill three weeks, and the Senate Calendar filled up in the meantime. On April 7, when the Senate Committee Substitute was reported out of Committee, it was sixty-third on the calendar. The bill moved up very slowly on the calendar, and on April 28, two days 
before the end of the session, HB 1172 was only forty-third on the Senate Calendar--a hopeless situation. As Meryl Atterberry was later to remark, "A miracle seemed the only thing that would save the bill . . ."58

Then, Sen. George E. Murray (Creve Coeur), a member of the Senate Committee which had shredded the original bill, volunteered to add the contents of HB 1172 as an amendment to HB 1021, another library bill which was third on the Senate Calendar. HB 1021 provided, among other things, for the establishment of public libraries in communities having a population of 4,000. Ironically, this bill had not even been endorsed by the Missouri Library Association. Senator Murray and HB 1172 sponsor, Representative Goode, met with Rep. Bob Griffin (Cameron), the sponsor of HB 1021, who was amenable to the idea of the "HB 1172 amendment" plan.

On the afternoon of April 29, 1976, the next-to-last day of the regular session, Senator Murray offered "Senate Amendment No. 1" to HB 1021 on the Senate floor. This amendment contained the basic information from HB 1172, along with the two added provisions Atterberry and Schramm desired. After Senator Murray's favorable comments, the Senate adopted the amendment. Another unrelated amendment was also attached to the Senate bill. Finally, HB 1021, as amended, was approved by a vote of 25-0, with Chairman Waters of the Senate Committee absent. HB 1021 now went back to the House for re-approval, as it had been amended with the depository legislation amendment. 59 
In the House, Representative Griffin, sponsor of the now-important $\mathrm{HB}$ 1021, moved the House approve the amendments. These amendments were approved, 140-2, and House Bil1 1021, as amended with the state depository legislation, then passed by a vote of 143-1.60 According to Representative Goode, Rep. Kenneth J. Rothman (Clayton), the majority floor leader, was "very instrumental" in getting the bill finally approved in the House. The miracle had happened--and state depository legislation was now a reality. ${ }^{61}$

Betty Schramm wrote her depository bill coordinators a "good news memo" on the next day, April 30, in which she described the hectic events of the past few days. She was quite pleased with all the "marvelous support and help" the coordinators had provided. Meryl Atterberry, however, was to comment later in a more sober fashion about the effect of the MLA lobbying effort. She felt the area coordinators were not that well-organized nor their roles properly defined. Furthermore, Atterberry had received little help from the MLA Legislative Committee, whose "network had fallen into disuse." She summed up her views this way:

Though our effort was the strongest mounted by MLA in a long time, I still felt it could have been much stronger. We had very little personal presence in the Capitol, which could have been a fatal lack - that's why ASUM was so helpful.62

The Associated Students of the University of Missouri (ASUM) was a student lobbying organization at the State Capitol. ASUM worked for legislation which would ultimately serve 
student's interests, and HB 1172 was one of ASUM's priorities. Atterberry later wrote ASUM Executive Director, Douglas Vieh1and: "I am thorough1y convinced that the 1obbying of ASUM was one of the crucial factors in the passage of a depository bill its first time out." 63

The legislative session ended, and HB 1021--including the state depository legislation amendment--now awaited Governor Bond's signature. Only 13\% of the bills introduced were passed in this short session, and few had given this piece of legislation much chance of passage in its first attempt. Even ASUM commented at one point in the session that HB 1021 "was delayed earlier in the session because it wasn't controversial enough to inspire legislative interest." 64 However, due to the fine background work of the MLA Subcommittee on State Documents Depository Legislation, and the zealous efforts of Meryl Atterberry and Betty Schramm, a five-year dream had become reality. Much effort had been expended in this project, but the rewards were yet to be reaped--state documents being distributed to depository libraries across the state of Missouri. 
PART III

Missouri librarians paused to relax and collect their thoughts. Most of their original bill had been scrapped, but they did get a solid piece of legislation through the General Assembly. Specifically, the key provision requiring agencies to deposit "sufficient" copies of their publications with the State Library had been included in the bill which passed in those hectic final two days of the session. A year later, Atterberry reflected on the legislation:

We are satisfied with the final law, . . Though it is much shorter than our version, we were most pleased to preserve flexibility in the number of copies to be requested of agencies - we thought the legislature might pin us down to a definite number. 65

Atterberry was hopeful that sections omitted from the bill, such as basic standards for depository libraries, could later be regained through administrative regulations.

The Governor, however, had to sign the bill. Atterberry grew rather anxious as the days passed, and on May 26, she wrote another memo to members of the MLA Subcommittee on State Documents Depository Legislation, urging them to write the Governor and ask him to sign HB 1021. Fina11y, Governor Bond signed the bill on June 24, 1976, in the presence of the one person most responsible for the state depository system, 
Meryl Atterberry. The new state documents depository law would become effective on August 13, 1976. ${ }^{66}$ The next step would be implementation of that law.

Meryl Atterberry was concerned about several factors in the implementation of the state documents depository law. Many unanswered questions remained--which libraries would be depositories, what types of publications would be distributed, and what standards and procedures should be followed. Also, the State Library had some serious questions to consider, including the cost for the upcoming documents program--would there be enough financial resources in the current Fiscal Year 1976-77 budget to implement the new depository program? Once the program was implemented, how would the documents be accessed bibliographically? Was OCLC cataloging a reasonable possibility? Even more important, would state agencies cooperate with this new law and send their publications to the State Library? Addressing this latter point, Atterberry wrote her colleagues:

I believe that it is very important psychologically to let state agencies know as soon as possible about the depository law. We must let them know that we mean business about carrying out the provision of the act. . . . Enforcement of the law would be much damaged by drifting for a period of months without letting agencies know that we do expect them to comply with it. 67

On July 1, 1976, approximately thirty librarians came to Jefferson City to discuss the state documents depository law. Specifically, the librarians were asked to provide input in 
the drafting of standards for depository libraries. Atterberry hoped to get these standards filed with the Secretary of State as official rules, but her time was limited. If filed by July 15 , as she hoped, these rules would be codified by October 11. Furthermore, January 1, 1977 was the target date for the mailing of documents to the depositories, and Atterberry wished the legalities to be resolved by then. Atterberry emphasized the importance of this July 1 meeting: "Since our law is brand-new, and we have so many good librarians in Missouri who are excited about state documents, we have a unique opportunity to set up a model system."68

The meeting began with Atterberry reflecting on the past achievements of the MLA Subcommittee on State Documents Depository Legislation. Admitting "some said we were crazy to try" in the short session of the Legislature, Atterberry recounted the final hectic days of the legislative session. She then thanked two key people on the MLA Subcommittee: 1) Eddie Altis, Chairman, described by Atterberry as "Mr. Government Documents," who had the "privilege which most of us could do without" of testifying before the Senate Committee which shredded the original bill; and 2) Betty Schramm, "our political strategist," who found a sponsor for HB 1172 and gathered much behind-the-scenes advice on guiding a bill through the General Assembly. 69

Atterberry next discussed the purpose of the meeting. She asked the librarians for some sort of consensus on what they were trying to build and for ideas on how best to achieve 
such a goal. Then, the group addressed the business of establishing standards for depository libraries. The librarians deliberated a long time before resolving several issues. Concerning the definition of a "depository" library, the group decided selection of depositories would be on the basis of geographical distribution, broadness of clientele served, and the willingness to follow the new standards established by the librarians. These standards called for the easy accessibility of Missouri documents for Missouri residents. Also, the standards required the speedy processing of Missouri documents, with a professional librarian responsible for the servicing of the documents.

The librarians proposed another rule concerning the types of depository libraries which simply reinstated the "full" and "partial" depository designations, originally cited in $\mathrm{HB}$ 1172. The only point of controversy was the automatic designation, upon request, of state university libraries as state documents depositories. Some representatives of large public libraries felt that academic libraries were not always oriented to serving the community and should apply on the same basis as other libraries. Atterberry sought to avoid any charge of unequal application of the law, and thus wrote up the rule requiring state universities to meet the same requirements as public libraries in becoming depositories.

Finally, the librarians specified the need for some basic reference works to be included in all depositories. These important works, termed "core" documents, would be so 
designated by the State Library. Also, the librarians wanted two types of selection: agency and subject. However, Atterberry felt that subject selection would involve too much work on the already overburdened State Library staff and opted to work only with agency selections. Under this plan, full depositories would receive all publications from all state agencies. Partial depositories would receive the "core" documents, as well as "all the publications of at least one of the major departments of state government." Partial depositories were free to choose any state agency they so desired. 70

This July 1 meeting of documents librarians was largely a success. Meryl Atterberry incorporated the librarians' ideas into the proposed rules for state publications, dividing the rules into two categories: (1) standards for depository libraries; and (2) types of depository 1ibraries. ${ }^{71}$ Atterberry submitted these rules to the Coordinating Board for Higher Education on July 12, where they were approved. Two days later, July 14 , the rules were filed with the Secretary of State for publication in the August issue of Missouri Register. This publication announced proposed new rules and regulations, and after a thirty-day period for public comment, final rules incorporating any improvements suggested by the comments would be filed.

In the August 2, 1976 issue of Missouri Register, the proposed rules for state depository libraries were published. 72 Only two public comments were received in the thirty-day period, 
but one substantive change resulted in the section pertaining to partial depositories. The original rule specified that partial depositories were to receive "all the publications of at least one of the major departments of state government." In reality, this could have resulted in many unused and unwanted publications in a partial depository library. The rule was changed to allow for more flexibility:

- . the State Library shall define categories of publications for selection by depository libraries. A category may be comprised of the publications of a department or division of state government or some other logical grouping of publications. Each partial depository library must select at least one category of publications to be received in addition to the core collection. 73

What should have been a rather simple process of final approval became unexpectedly complicated by the Coordinating Board for Higher Education. The Board simply had to approve the rules, as it had done earlier, with the one rule change. The final rules would then be filed with the Secretary of State's Office, published again in the Missouri Register, and become effective ten days later. Meryl Atterberry anticipated no problem whatsoever. After all, the Coordinating Board had approved the rules July 12, and the rules had survived a thirty-day public scrutiny with only one minor change. However, the Board had different plans for this routine matter. On September 13, 1976, the Coordinating Board for Higher Education approved the rules at its meeting. However, the Board decided not to file the rules in the Missouri Register. 
Board members were resisting in principle the filing of rules, and this was one way of showing defiance. Normally, rules would have the same effect as laws, but without publication in the Missouri Register, rules were unenforceable. In effect, the Board was stripping the depository rules of any legal clout.

Atterberry was naturally upset by this turn of events. In a long memo to her superiors, she wrote:

The Coordinating Board's attitude toward the filing of rules is certainly unusual. . the Board's handling of its organizational rule is unique in state government. 94

Specifically, the Board was quibbling with the definition of the word, "rule," and had decided the depository "rules" did not affect the public. Atterberry, however, countered with this argument:

If we are creating standards to determine who will receive copies of state publications and who will not, we are affecting the rights or procedures available to the public. . . . it is entirely possible that a library may want some justification as to why it is excluded from the free distribution. The library will have a senator ${ }_{5}$ and representative who will want
to know also.

Atterberry wished to have these rules in effect before depository distribution began in January 1977. The Coordinating Board, however, refused to cooperate. Again, at its November 1976 meeting, the Board declined to file the approved rules with the Secretary of State's Office. It was not until 
July 23, 1977, that the Coordinating Board voted to file these rules with the Secretary of State. On September 1, 1977, the proposed rules were again published in the Missouri Register. 76 No public comments, favorable or unfavorable, were received, and the revised rules became effective on November 11, 1977. What should have been a three-month process had been turned into a fifteen-month ordeal, and provided one of the strangest episodes in the history of the Missouri documents depository system.

In August 1976, Meryl Atterberry sent a "Survey of State Documents Received by Missouri Libraries" to all Missouri public and academic libraries. She was responding to the consensus feelings of the librarians at the July 1 meeting, who felt that a select group of Missouri documents (core documents) should be included in all depository libraries, both full and partial. This lengthy survey of 110 titles or types of publications was used by the State Library to determine "with a much more reliable basis" the core list of documents. The survey results, as reported in September 1976, proved to be "valuable input" for Atterberry. Over eighty libraries responded to the survey, with Missouri's Official Manual edging out Missouri Conservationist for the top spot. Just as noteworthy was the number of titles not received by libraries. Forty titles ( $36 \%$ of all listed) on the survey were received by less than ten Missouri 1ibraries. 77 Atterberry now had a better idea just which documents were received-or not received--by Missouri libraries. 
In October 1976, the annual MLA Conference in Springfield cited HB 1172 sponsor, Rep. Wayne Goode "for his efforts in causing the passage of legislation which will contribute substantially to the enlightenment of Missouri's people." Also, Sen. George E. Murray was cited for using his "legislative skill" to guide the legislation through the Senate. ${ }^{78}$ Finally, a surprise Iuncheon was given for Meryl Atterberry to honor her zealous efforts for making depository legislation a reality.

At this MLA Conference, Atterberry gave a presentation on the status of the depository system. The General Assembly passed the bill April 29; Governor Bond signed it June 24; and, the law became effective August 13, 1976. Stil1, no documents were being sent to depository libraries--why? It was a valid question, yet Atterberry's intentions were to do it right--even if that meant delay. As early as June 10, 1976, Atterberry had notified State Librarian Charles 0'Halloran:

We will plan to begin actual distribution of depository documents January 1, 1977. We will inform libraries and agencies of this intention so they may plan accordingly. 79

As late as October 1976, however, no depository libraries had been established. Much work remained to be finished in a short amount of time.

On October 20, 1976, Meryl Atterberry sent a memo to all public and academic libraries in Missouri. She invited those librarians interested in depository status to fill out an enclosed "Application for Designation as State Publications 
Depository Library."80 In addition, Atterberry announced that the core documents list would be compiled within two months after discussions with the various state agencies. Atterberry pointed out that implementation of the state documents depository law "cannot be carried out too hastily if it is to be effective." She also distributed a tentative calendar of events for the depository system, with these two main features:

1) Distribution of core documents (those basic items which all depository libraries must receive) will begin January 3, 1977.

2) Distribution of all other documents will begin in the spring, with all agencies' documents to be included by July $1,1977.81$

Finally, Atterberry announced the formation of a State Documents Advisory Committee composed of "librarians who are familiar with state documents" to aid her in designating depositories, determining which Missouri publications would be on the core 1ist, selecting "categories" for partial depositories, and developing other internal procedures. This Committee of nine librarians included Eddie Altis and other members of the origina1 MLA Subcommittee on State Documents Depository Legislation. 82

Three months before depository distribution was set to begin, Atterberry visited various state agencies, trying to establish a friendly rapport between each agency and the State Library. In general, this was not a difficult task, for the State Library often worked closely with state agencies 
on basic library reference service. This situation, however, was different. The new depository law required state agencies to supply "sufficient" copies of their publications to the State Library. The State Library requested each agency to appoint a "publications contact" who would see to it that "sufficient" numbers of a publication were sent to the State Library. With fourteen major departments and many more sma11er divisions and bureaus, much time was required to coordinate these efforts. To expedite this whole process, Atterberry prepared a "State Agency Handbook" specifically for state agencies to aid them in their understanding of and compliance with the new depository law. 83

On December 9, 1976, Meryl Atterberry met with the State Documents Advisory Committee to decide two important matters: 1) which depository applications would be rewarded with depository status; and 2) the core list of Missouri documents. First, the Committee discussed the depository library applications. Twenty-nine applications were received, twelve seeking full status and seventeen desiring only partial depository status. Two of the full status applicants were dropped to partial status, one because of space limitations, the other because the library did not wish to receive all publications. Also, the Audrain County Library in Mexico was refused depository status altogether because the library had "apparently misunderstood the purpose of the application slightly."84 Finally, the Committee approved ten full depositories and eighteen partial depositories for state publications. 85 
How critical was the Committee in making its selections? In the original application memo, Atterberry had stated: "Adequate geographic coverage of the state without needless duplication will be a major criterion in the designation of depositories. . . 86 Yet, one interesting episode occurred during the depository selection process. Three libraries in St. Joseph requested depository status. The Committee, aware of Atterberry's statement to avoid "needless duplication" decided, by unanimous vote, upon only two depositories for St. Joseph. However, at a later time in the meeting, a member pointed out that three depositories were being designated in Cape Girardeau County, which she described as a "comparable situation" to the three proposed libraries in St. Joseph. So, the St. Joseph vote was reconsidered, and by another unanimous vote, St. Joseph was awarded the third depository library originally requested: 87 Certainly, with six depositories in the St. Louis metropolitan area and three in St. Joseph, one might question if "needless duplication" existed. Perhaps the Advisory Committee felt it was best not to be overly discriminating at this time. Furthermore, the librarians realized that the General Assembly would be meeting in one month to decide on appropriations for the depository system. This was not the time to antagonize any influential citizens.

The Advisory Committee next decided on the list of core documents. After deliberating for several hours, approximately fifty titles were chosen as core documents. These documents 
were selected "for their value in helping citizens understand and gain access to their government, providing Missouri statistical or directory information or providing news on important subjects." 88 Many of these titles fell under the classification of directories or annual/biennial reports. Furthermore, the State Library took responsibility for determining the core status of any forthcoming publications issued by state agencies. 89

Atterberry sent the Committee's decisions to each new depository library, and enclosed a map and listing of all designated depositories. The time was very close for the new state depository system to begin operations. Atterberry was working on a manual for the depository libraries, which explained the depository law, core documents, and sample procedures for processing these documents. She also was busy informing the appropriate state agencies of the core documents needed from their agency. Agencies were not asked to send other documents at this time--only core documents as they were published. However, some agencies were eager to send other publications to the depositories. The State Library had not determined the selected categories of documents from which the partial depositories could choose, so these extra documents were treated as core documents, with an option of later disposal for the partial depositories. One agency, the Division of Budget and Planning, had been sending copies of its documents to the State Library since early 1976, and Meryl Atterberry had distributed these to the state university libraries. 
Finally, the long-awaited day arrived. On January 31 , 1977, the Missouri State Library sent to all twenty-eight depositories its first depository shipment of twenty Missouri documents. Along with this shipment went shipping list \#1 which gave the title, agency, and classification number for each document. ${ }^{90}$ This arrangement was to continue for the next few months, with all depositories receiving all the documents. The types of documents included in the early shipments were mostly publications of the executive agencies of Missouri state government. The legislative and judicial branch documents would be added later. However, the whole program was contingent on one key ingredient: money. And once again, the focus shifted to the Missouri Legislature. When the General Assembly approved HB 1021, the legislators realized from the fiscal note attached to the bill what the expenses would be. Nevertheless, passage of the depository legislation did not automatically include funding. Funds appropriated for State Library operations in the Fiscal Year 1976-77 budget were used to get the depository system started in January 1977. Full implementation, however, with a parttime cataloger and additional equipment, was contingent solely on legislative appropriations.

The State Library was seeking an emergency $\$ 5,000$ appropriation for the months of April-June 1977. If this request was approved, the depository law could be implemented much faster. The request was justified this way: 
With this amount the program can begin on April 1, 1977. The present plan is to contract for the receipt, processing and shipping of these materials in order to make them available as quickly as possible to the citizens of Missouri through the depository libraries. 91

This referred to the State Library's decision to contract with the Library Services Center of Missouri in Jefferson City for the actual distribution of depository documents. The Library Services Center was a cataloging cooperative of which the Missouri State Library was a member. More space was available there than at the State Library to handle document shipments. Also, in utilizing the Library Services Center, the State Library would not need to ask the General Assembly for an additional staff person.

The Fiscal Year 1977-78 appropriation request for the depository system was $\$ 20,000$. However, as Eddie Altis pointed out in a letter asking for support, the amount was buried in the State Library's budget, in a category labeled "professional \& technical services." Furthermore, there was no justification cited for the amount. Altis enclosed a list of the legislators on the House and Senate Appropriations Committees, and urged librarians in their particular districts to contact the legislators involved. Altis stated that the budget request "represents the bare minimum needed to operate the program." Moreover, he warned librarians: "While the sum being requested is so small that it should not cause controversy, it could easily be lost through lack of understanding by the House and Senate Appropriations Committees." 92 
There was no lack of understanding this time. Rep. Wayne Goode, the original sponsor of depository legislation, was Chairman of the House Appropriations Committee, and he saw to it that the emergency and regular funding requests were both passed. In the Senate, the Chairman of the Senate Appropriations Committee, Sen. Donald Manford (Kansas City), questioned citizen support for the depository program. Nevertheless, both bills passed the Senate, and the depository program became fully funded, beginning from April 1977 through Fiscal Year 1977-78.

In the meantime, Atterberry sent each depository library a publication describing the processing of Missouri documents, along with another booklet describing the Missouri documents classification scheme. ${ }^{93}$ Also, formal depository agreements were sent to each depository in February. 94 These agreements basically insured the mutual responsibility of the State Library and the depository library.

With the appropriations now available, the State Library began full implementation of the depository program. The State Library did contract with the Library Services Center of Missouri in Jefferson City for distribution and cataloging services of Missouri documents. Although its cataloging service was not yet operational, the Library Services Center began the regular weekly distribution of documents with shipment $\# 10$ on June 29,1977 . The State Library Documents Division was thus relieved of one of its more time-consuming tasks. 
On June 10, 1977, a "Depository Selection List" for Missouri documents was sent to the seventeen partial depositories (Sullivan Public Library had withdrawn as a depository due to the large volume of material). ${ }^{95}$ The partial depositories had the opportunity of selecting documents from a possible fifty-one categories. A "category" generally consisted of the publications of an entire division or agency. When all depositories made their selections, the State Library then totaled the requests from the various categories and notified the particular state agencies of an exact number of documents to be supplied. This total varied with each agency, ranging from a low of eighteen to a maximum of thirtyfive documents. This latter figure was well within the original estimates the State Library had planned in 1975. In October 1977, the partial depositories started receiving only the selections they had chosen, along with any core documents designated that week. Thus, the distribution system for Missouri documents was finalized by October 1977 .

In August 1977, Anne Parkison was hired as the first part-time state documents cataloger. Parkison was employed by the Library Services Center, but dealt on1y with Missouri documents and was supervised by the Government Documents Coordinator at the State Library. The purpose of descriptive cataloging for state documents was to save depositories the time and expense involved in cataloging. Parkison began inputting documents into the OCLC data base in September 1977.96 OCLC produced catalog cards which were sent to both full and 
partial depository libraries. These cards contained Library of Congress and Dewey classification numbers, as well as a unique MoDoc number assigned to the publication. The Missouri documents (MoDoc) classification scheme, which was used by most Missouri depository libraries, was designed to parallel the Superintendent of Documents (SuDoc) classification scheme for U.S. government publications. Thus, by inputting Missouri documents (with three classification schemes) into the OCLC data base, cataloging data would be available to other Missouri libraries as well as to libraries around the United States with access to OCLC.

The Missouri state documents depository system was now completed, having taken four years since the formation of the MLA Subcommittee on State Documents Depository Legislation. This successful venture was truly the result of the combined efforts of many people--Eddie Altis, Betty Schramm, and the other members of the MLA Subcommittee; the documents librarians throughout the state of Missouri; and those interested librarians and "friends" of Missouri libraries who lobbied for this legislation. Furthermore, depository legislation would have been impossible without the administrative support of the Missouri State Library, which authorized Mery1 Atterberry to devote her time to this effort. The State Library even hired another librarian in 1974 to handle U.S. government documents, thus freeing Atterberry from this task.

The fact remains, however, that the Missouri depository system would not have become a reality without the tremendous 
efforts put forth by Meryl Atterberry of the Missouri State Library. From the time of her hiring in 1971, Atterberry had devoted most of her time and energy to the development and implementation of the Missouri documents depository system. As she later commented, "I think this type of effort requires a large time commitment on someone's part, whether located at the State Library, university, or another library."97 An objective observer could only conclude that Missouri was indeed lucky to have that "someone" be Meryl Atterberry. Missourians were now able to gain quicker access to, and more knowledge of, important state information. Librarians could now point with pride at their Missouri documents collections. To Meryl Atterberry, however, this was not just a victory for librarians. As she said, "We always made this appear to be not a 'library bill,' but one of benefit to the 'citizens of Missouri."'98 Atterberry's dream in 1971 became a reality in 1977, and Missourians will be benefiting for many years to come. 


\section{FOOTNOTES}

1. U.S., Library of Congress, Monthly Checklist of State Publications 60 (December 1969): [1].

2. Harland Bartholomew and S. Herbert Hare, Facts, Findings and Recommendations on State Planning for Missouri; A Report to the National Resources Board (Jefferson City: Missouri State Planning Board, 1935), p. 323 .

3. Mery1 Atterberry to Bernadine Hoduski, October 25, 1972, File 20, Missouri State Library, Jefferson City, Missouri (hereafter cited as MSL).

4. Mery1 Atterberry to Eddie Altis, November 13, 1972, File 20, MSL.

5. Dallas Y. Shaffer, "State Document Legislation: Nebraska A Case Study," Government Publications Review 1 (Fal1 1973): 19-28.

6. MLA Committee on Government Documents, Minutes of meeting of September 28, 1973, File 20, MSL.

7. See Appendix 1 for preliminary bill draft--"discussion draft."

8. Meryl Atterberry, August 16, 1974 letter, File 2, MSL.

9. Ibid.

10. Meryl Atterberry, Memorandum to State Documents Depository Legislation Subcommittee, September 12, 1974, File 2, MSL.

11. Atterberry, August 16, 1974 letter.

12. See Appendix 2 for revised draft, September 5, 1974.

13. Atterberry, Memorandum, September 12, 1974.

14. See Appendix 3 for MLA State Documents Resolution. 
15. State Documents Resolution, File 9, Enclosure B, MSL.

16. Betty Schramm to Government Documents Librarians, November 12, 1974, Schilling File 1, Documents Office, University of Missouri-Columbia Library, Columbia, Missouri.

17. See Appendix 4 for State Documents Depository Legislation Questionnaire.

18. Ibid.; State Documents Depository Legislation Subcommittee Questionnaire, January 31, 1975, File 2, MSL.

19. State Documents Depository Legislation Subcommittee, Minutes of Meeting of February 28, 1975, Schilling File 1, Documents Office, University of Missouri-Columbia Library, Columbia, Missouri.

20. State Documents Depository Legislation Questionnaire, January 31, 1975.

21. Eddie Altis to Sally Schilling, February 10, 1975, Schilling File 1, Documents Office, University of MissouriColumbia Library, Columbia, Missouri.

22. Fiscal note worksheet in Fiscal Note Manual (7-73), File 14, MSL.

23. See Appendix 5 for revised draft, February 28, 1975.

24. Minutes of meeting of February 28, 1975.

25. Notes on Government Documents Committee meeting of 18 July 1975, Schilling File 1, Documents Office, University of Missouri-Columbia Library, Columbia, Missouri.

26. Meryl Atterberry to Eddie Altis, June 4, 1975, File 16, MSL.

27. Mery1 Atterberry to Robert F. Gaines, July 27, 1977, File 9, MSL.

28. Reports and Publications of State Agencies, p. 1, File 14, MSL.

29. Fiscal note worksheet for Fiscal Note No. 1877, File 14, MSL.

30. Ibid.

31. Meryl Atterberry, "Missouri Documents to the People," October, 1975, p. 3, File 2, MSL. 
32. Eddie Altis to Meryl Atterberry, June 6, 1975, File 16, MSL.

33. Notes on meeting of 18 July 1975.

34. Ibid.; Meryl Atterberry, Memorandum to Charles 0'Halloran and Susanna Alexander, Ju1y 21, 1975, File 2, MSL.

35. Atterberry, Memorandum, July 21, 1975.

36. See Appendix 6 for State Documents Depository Survey.

37. Depository Interest Survey 1975, File 7, MSL.

38. Preliminary cost estimate, August 1975, File 14 , MSL.

39. Betty Schramm to Meryl Atterberry, August 13, 1975, File 2, MSL.

40. Atterberry to Gaines, July 27, 1977.

41. "Missouri Politics," Focus/Midwest 11 (no. 68), [1976?], p. 12 .

42. James C. Kirkpatrick to Charles O'Halloran, September 15, 1975, File 16, MSL.

43. See Appendix 7 for HB 1172, prefiled.

44. Eddie Altis to Subcommittee, December 23, 1975, File 2, MSL.

45. Betty Schramm to Directors of Missouri Libraries, January 4, 1976, File 3, MSL.

46. Meryl Atterberry, Urgent Memorandum to area coordinators, January 27, 1976, File 3, MSL.

47. Resolution \#1985, February 2, 1976, File 3, MSL.

48. See Appendix 8 for HB 1172, perfected.

49. Wayne Goode, February 16, 1976, File 3, MSL.

50. Meryl Atterberry, Good News Memo \#2 to Depository Bil1 Coordinators, March 11, 1976, File 3, MSL.

51. Betty Schramm, Urgent Memorandum to area coordinators, March 24, 1976, File 3, MSL.

52. See Appendix 9 for HB 1172, Senate Committee Substitute. 
53. Betty Schramm, Memorandum to depository bill coordinators, April 14, 1976, File 3, MSL.

54. Mery1 Atterberry and Betty Schramm, Senate Committee Substitute for House Bill 1172, no date, File 3, MSL.

55. Meryl Atterberry, "New in Documents," Show-Me Libraries 27 (June 1976): 9.

56. Atterberry and Schramm, Senate Committee Substitute.

57. Betty Schramm, Memorandum, April 14, 1976.

58. Atterberry, "New in Documents," 9-10.

59. Journal of the Senate, Missouri 78th General Assemb1y, 2d sess. (Jefferson City, 1976), 1025-26.

60. Journal of the House, Missouri 78th General Assembly, 2d sess. (Jefferson City, 1976), 1833-35.

61. See Appendix 10 for HB 1021, truly agreed and finally passed.

62. Atterberry to Gaines, Ju1y 27, 1977.

63. Mery1 Atterberry to Douglas Viehland, June 7, 1976, File 16, MSL.

64. "State Depository system would help students," Briefcase 1 (April 8, 1976): 1. (Found in File 3, MSL).

65. Atterberry to Gaines, July 27, 1977.

66. See Appendix 11 for depository law in Missouri Revised Statutes.

67. Meryl Atterberry to Charles 0'Halloran and Susanna Alexander, May 25, 1976, File 4, MSL.

68. Mery1 Atterberry, Memorandum to Librarians, June 23, 1976, File 4, MSL.

69. Mery1 Atterberry, hand-written notes of July 1 , 1976 presentation, File 4, MSL.

70. Mery1 Atterberry to Librarians, July 30, 1976, File 4, MSL.

71. See Appendix 12 for proposed rules for state publications.

72. 1 MoReg 154-55. 
73. Order of Rule making, File 4, MSL.

74. Meryl Atterberry, Memorandum to Charles O'Ha1loran and Susanna Alexander, October 25, 1976, File 18, MSL.

75. Ibid.

76. See Appendix 13 for September 1, 1977 Missouri Register rules.

77. Meryl Atterberry, Memorandum to Missouri libraries, October 20, 1976, File 4, MSL.

78. MLA citations, October 14, 1976, File 4, MSL.

79. Mery1 Atterberry, Memorandum to Charles O'Halloran and Susanna Alexander, June 10, 1976, File 4, MSL.

80. See Appendix 14 for Application for Designation as State Publications Depository Library.

81. Atterberry, Memorandum, October 20, 1976.

82. $\quad$ Ibid.

83. Meryl Atterberry, State Agency Handbook (Jefferson City: Missouri State Library, 1977). MO HI.Li2: D66

84. Applications for Depository Designation, December 9, 1976, File 8, MSL.

85. See Appendices 15 and 16 for map and list of original state depository libraries.

86. Atterberry, Memorandum, October 20, 1976.

87. State Documents Advisory Committee, Minutes of meeting, December 9, 1976, File 19, MSL.

88. Mery1 Atterberry to depository libraries, December 16, 1976, File 19, MSL.

89. See Appendix 17 for list of core documents.

90. See Appendix 18 for shipping 1 ist $\# 1$.

91. Emergency or Supplemental Appropriation Request (Form 12), File 6, MSL.

92. Eddie Altis, Memorandum to State Documents Depository Libraries, January 17, 1977, File 6, MSL. 
93. Missouri State Documents: Preliminary Guide for Depository Libraries. January 1977. MO HI.Li2: D44; Missouri State Documents Classification: Post-Reorganization Agency Codes and Form Divisions. January 1977. MO HI.Li2: D65.

94. See Appendix 19 for depository agreement.

95. See Appendix 20 for depository selection 1ist.

96. Meryl Atterberry, "State Depository Documents Update," Show-Me Libraries 29 (October 1977): 20.

97. Atterberry to Gaines, July 27, 1977.

98. $\quad$ Ibid. 


\section{CHRONOLOGY}

$\underline{1971}$

July

Meryl (Wold) Atterberry hired as Government Documents Librarian at Missouri State Library.

$\underline{1972}$

October 19

Informal documents meeting at annual Missouri Library Association (MLA) Convention.

1973

January 23

Missouri Committee on Government Documents receives formal recognition.

September 28

Annua1 MLA Conference; State Documents Depository Legislation Subcommittee established.

$\underline{1974}$

September 5

First meeting, State Documents Depository Legislation Subcommittee.

September 20

Annua1 MLA Conference; Resolution supporting state documents legislation approved.

October

Legislative Committee of MLA promises support.

$\underline{1975}$

January

Distribution of state documents questionnaire on availability of documents.

February 28

Second meeting, State Documents Depository Legislation Subcommittee. 
$\underline{1975}$

July 18

August 22

September 12

October 22-24

December 1

$\underline{1976}$

January 7

January 13

January 26

February 17

February 25

March 9

March 10

March 17

March 23

April 7

April 29

April 29

April 30
Third meeting, State Documents Depository Legislation Subcommittee.

Survey of interest in becoming depository.

Coordinating Board for Higher Education approves depository plan.

Annual MLA Conference; "open" meeting presentation and information booth on state documents.

Rep. Wayne Goode prefiles House Bill No. 1172, an act to "establish and maintain a depository library system . . ."

House Bill (HB) 1172 introduced on first day of new legislative session.

HB 1172 referred to Committee on Governmental Organization.

House committee hearing on HB 1172.

Bill reported from committee with a "DO PASS."

HB 1172 perfected.

House passes HB 1172, 129-0.

HB 1172 read in Senate for first time.

HB 1172 assigned to Senate Committee on State Departments.

Senate committee hearing on $\mathrm{HB} 1172$.

Senate Committee Substitute for HB 1172 reported out of Senate committee.

Contents of HB 1172 attached as amendment to HB 1021, and Senate passes, 25-0.

House passes HB 1021, with its state depository amendment, 143-1.

Legislative session ends. 
$\underline{1976}$

June 24

Governor Christopher (Kit) Bond signs $\mathrm{HB} 1021$ into law, effective August 13.

July 1

Librarians meet in Jefferson City to draft standards.

July 12

Coordinating Board for Higher Education approves standards for depository libraries.

July 14

Rules regarding depositories filed with Secretary of State.

August 2

August 26

October 20

December 9

December 16

$\underline{1977}$

January 31

May-June

June 10

June 29

August

September 1

October

November 11
Missouri Register (vol. 1, \#4) publishes proposed depository rules and regulations.

"Survey of State Documents Received by Missouri Libraries" distributed by State Library.

Applications for designation as state depository libraries sent to libraries.

Meeting of State Documents Advisory Committee.

Libraries notified of depository selection.

First depository shipment of Missouri documents sent to depository libraries.

State Legislature passes appropriation bills funding depository program, FY 1977-78.

Depository Selection List sent to partial depositories.

Library Services Center initiates document distribution service with shipment $\# 10$.

First state documents cataloger hired.

Missouri Register (vo1. 2, \#9) publishes revised depository rules and regulations.

Partial depositories begin receiving only selected documents chosen in June survey.

Depository rules and regulations become effective. 


\section{LIST OF APPENDICES}

1. Preliminary bill draft--"discussion draft".......63

2. Revised draft, September $5,1974 \ldots \ldots \ldots \ldots \ldots \ldots \ldots \ldots$

3. MLA State Documents Resolution................69

4. State Documents Depository Legislation

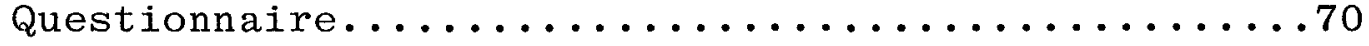

5. Revised draft, February $28,1975 \ldots \ldots \ldots \ldots \ldots \ldots \ldots$

6. State Documents Depository Survey.................

7. HB 1172, prefiled..........................

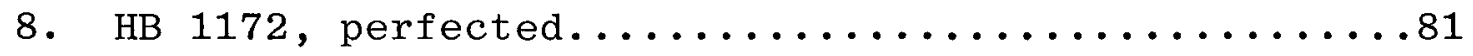

9. HB 1172, Senate Committee Substitute............87

10. HB 1021, truly agreed and finally passed.........90

11. Chapter 181.100 - 181.140 Missouri Revised Statutes.96

12. Proposed rules for state publications...........97

13. September 1, 1977 Missouri Register............99

14. Application for Designation as State Publications

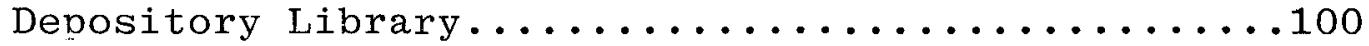

15. Map of original state depository libraries.......102

16. List of original state depository libraries......103

17. List of core documents........................

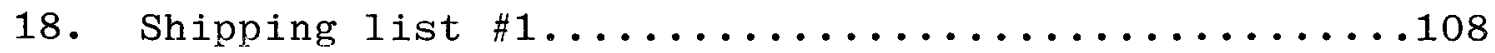

19. Depository agreement..........................

20. Depository selection 1ist..................112 
to establish a depository library system for Missouri state publications.

\section{1}

2

3

4

5

6

7

8

9

Section 1. As used in this act, the following words and terms mean:

(1) "Print" includes all forms of printing and duplicating, regardless of format or purpose, with the exception of correspondence and interoffice memoranda;

(2) "State publications" includes all multiply-produced publications printed or purchased for distribution by the state, the legislature, constitutional officers, any state department, committee, or other state agency supported wholly or in part by state funds;

(3) "State agency" includes every state office, officer, department, division, bureau, board, and commission, whether legislative, executive, or judicial, and any subdivisions of each, including state-supported institutions of higher education.

(4) "State department" includes the fourteen major administrative units of state government created by the State Reorganization Act of 1974.

Section 2. There is hereby created within the Department of Higher Education, under the State Library, a Depository Library Center. The State Librarian shall appoint a Depository Librarian who shall establish and administer a Missouri state publications collection and depository library system for the state of Missouri.

Section 3. Under the direction of the Coordinating Board for Higher Education, the State Library shall: (1) establish and administer, with 
the approval of the Coordinating Board, such rules and regulations as are required to carry out the provisions of this act; (2) develop and maintain standards for depository libraries, with the approval of the Coordinating Board; (3) designate depository libraries, in accordance with the provisions of this act; (4) advise state agencies annually of the number of copies of publications needed for distribution; (5) receive from state agencies on or about publication date the number of copies of each publication specified and distribute these to the depository libraries; (6) publish at least bi-monthly and distribute to depository libraries, other Missouri public, college, and university libraries, legislators, state agencies, other state libraries, and to other libraries upon request, an official indexed list of Missouri state publications with an annual cumulated index. Section 4. Every state agency shall, upon release, deposit a specified number of copies of each of its state publications with the Depository Library Center to meet the needs of the depository library system. The number of copies required for the depository, not to exceed [ ] copies, shall be certified to each agency annually by the Depository Librarian.

Section 5. After receipt of the state publications of any agency, the Depository Library Center shall distribute copies of such publications as follows: (I) Two copies to the State Archives for permanent preservation; (2) [ ] copies to the State Historical society; (3) two copies to the Library of Congress; (4) one copy to an additional national research library designated by the Depository Librarian; one copy to each full depository, as provided in Section 8 (a); (6) one copy to each partial depository which has elected to receive the publications of that agency, as provided in Section 8 (b). The center 
shall retain sufficient copies in the Missouri state Library for preservation, reference, and interlibrary loan purposes and for distribution in accordance with any agreements entered into with other states for the exchange of state publications.

Section 6. Each state department shall designate a publications officer, who shall be responsible for supplying the publications of that department, including all its subdivisions, to the Depository Library Center. The publications officer of each state de-

partment shall notify the Depository Iibrarian of his or her identity. Upon request, the publications officer shall supply the Depository Center with a complete list of the department's current state publications. State agencies which issue no publications during the year shall so notify the Depository Center in writing. Section 7. The Depository Library Center may [designate as depositories/ enter into depository contracts with] public libraries and college and university libraries which meet the standards for depository eligibility approved by the Coordinating Board for Higher Education. The standards shall include the following requirements: (1) ability of the library to receive, process, organize, and retain state publications; (2) willingness of the library to provide reference assistance and interlibrary loan service for depository publications; (3) such geographical distribution of libraries as will make publications conveniently accessible to residents in all areas of the state. Section 8. Depositories shall be of two types: (1) Full depositories shall receive all publications of all state agencies and shall maintain full collections of these publications for a minimum specified period. (2) Partial depositories shall be designated 

for the purpose of developing specialized collections of state publications in major subject areas. Partial depositories shall receive and maintain for a minimum specified period publications from specified state agencies, as agreed to by the Depository Library Center. Partial depositories shall be considered as supplementary to coverage of the state by full depositories. A partial depository shall meet the same standards for reference and interlibrary loan services as a full depository. Section 9. This act shall not affect the general public distribution of publications by state agencies, nor shall it affect the distribution of publications by the secretary of state under RsMo 2.091 \& 3.130 , except that each agency shall deposit the requested number of copies of each publication with the Depository Library Center. 
to establish a depository library system for Missouri state publications.

Section 1. As used in this act, the following words and terms mean:

(1) "Print" includes all forms of printing and duplicating, regardless of format or purpose, with the exception of correspondence and internal memoranda;

(2) "State publications" includes all multiply-produced publications printed or purchased for distribution by the state, the legislature, constitutional officers, any state department, committee, or other state agency supported wholly or in part by state funds;

(3) "State agency" includes every state office, officer, department, division, bureau, board, and commission, whether legislative, executive, or judicial, and any subdivisions of each, including state-supported institutions of higher education.

(4) "State department" includes the fourteen major administrative units of state government created by the state Reorganization Act of 1974.

(5) A depository is a designated place for collecting, maintaining, and making available to the general public publications issued by agencies of the Missouri state government.

Section 2. There is hereby created within the Department of Higher Education, within the State Library, a Depository Library Center and a depository library system for the state of Missouri. The State Librarian shall appoint a Depository Librarian who shall administer a Missouri state publications collection and depository library system.

Section 3. Under the direction of the Coordinating Board for Higher Education, the state Library shall: (1) establish and administer, with the approval of the Coordinating Board, such rules and regulations as are required to carry out the provisions of this act; (2) develop and maintain standards for depository libraries, with the approval of the Coordinating Board; (3) designate depository libraries, in accordance with the provisions of this act; (4) advise state agencies annually of the number of copies of publications needed for distribution; (5) receive from state agencies on or about publication date the number of copies of each publication specified and distribute these to the depository libraries; (6) publish at least monthly and distribute to depository libraries, other Missouri public, college, and university libraries, legislators, state agencies, other state libraries, and to other libraries upon request, an official indexed list of Missouri state publications with an annual cumulated index.

Section 4. Every state agency shall, upon release, deposit a sufficient number of copies of each of its state publications with the Depository Library Center to meet the needs of the depository library system. The number of copies required for the depository system shall be certified 
to each agency annually by the Depository Librarian. This requirement includes sale items, with the exception of the university presses, which shall be required to deposit 2 copies of each publication with the depository library center.

Section 5. After receipt of the state publications of any agency, the Depository Library Center shall distribute copies of such publications as follows: (I) Two copies to the State Archives for permanent preservation; (2) [ ] copies to the State Historical society; (3) two copies to the Library of Congress; (4) one copy to an additional national research library designated by the Depository Librarian; (5) one copy to each full depository, as provided in section 8 (a); (6) one copy to each partial depository depository which has elected to receive designated publications, as provided in Section 8 (b). The Center shall retain sufficient copies in the Missouri state Library for preservation, reference, and interlibrary loan purposes and for distribution in accordance with any agreements entered into with other states for the exchange of state publications.

Section 6. Each executive department, the General Assembly, and the Judicial branch, shall designate a publications officer, who shall be responsible for supplying the publications of that department or branch, including all its subdivisions, to the Depository Library Center. Each publications officer shall notify the Depository Librarian of his or her identity. The publications officer shall supply the Depository Center annually or upon request with a complete list of the department's current state publications.

Section 7. The Depository Library Center may enter into depository contracts with public libraries and college and university libraries which meet the standards for depository eligibility approved by the Coordinating Board for Higher Education. The standards shall include the following requirements: (1) ability of the library to receive, process, organize, and retain state publications; (2) willingness of the library to provide reference assistance and interlibrary loan service for depository publications; (3) such geographical distribution of libraries as will make publications conveniently accessible to residents in all areas of the state.

Section 8. Depositories shall be of two types: (1) Full depositories shall receive all publications of all state agencies and shall maintain full collections of these publications for a minimum specified period. (2) Partial depositories shall be designated for the purpose of developing specialized collections of state publications in major subject areas. Partial depositories shall receive and maintain for a minimum specified period designated publications, as agreed to by the Depository Library Center. Partial depositories shall be considered as supplementary to coverage of the state by full depositories. A partial depository shall meet the same standards for reference and interlibrary loan services as a full depository.

Section 9. This act shall not affect the general public distribution of publications by state departments, nor shall it affect the distribution of publications by the secretary of state under RsMo 2.091 and 3.130 , except that each agency shall deposit the requested number of copies of each publication with the Depository Library Center. 
WHEREAS, all citizens of Missouri have a right to information published by their state government and supported by their tax monies; and

WHEREAS, this information is not now easily available to citizens in all areas of the state; and

WHEREAS, the state of Missouri does not have a state deposistory law for distribution of state publications, and is one of the few states in the country without such a law; and

WHEREAS, the State Documents Task Force, the Government Documents Round Table, the Association of State Library Agencies, and the Interaivisional Committee on Public Documents of the American Library Association have recently approved suggested minimum standards for state servicins of state documents; and

WHEREAS, the state of Missouri does not meet any of the approved minimum standards relating to the distribution of state publications; and

WHEREAS, there is an urgent need for action to correct the inaccessibility to state publications: Now, therefore be it

RESOLVED, that the Missouri Library Association strongIy supports legislation to establish a depository library system for Misscuri state publications in order to make these publications available to Iibraries and citizens throughout the state; and be it further

RESOLVED, that the Missouri Library Association authorizes the State Documents Depository Subcomittee of the Documents Committee of the Missouri Library Association to continue preparation of a bill to establish a depository library system for Missouri state publications, to work with the Legislative Committee of the Missouri Library Association to gain legislative support, and to work to gain support of citizens throughout Missouri.

Approved by Missouri Library Association membership September 20, 1974 
STATE DOCUMENTS LEPOSITORY IEOISIATION SUBCOMIITTEE

Questionnaire

Name of Iibrary Total Response: 58 Librapies

Name of Parent Institution

Address

City

County

Name and Position of Person Completing Questionnalre

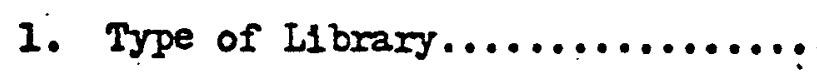

University

Four Year College

(6)

Tro Year College

Public

Other

2. Total number of volumes in collection............ 0-25,000

$25,000-50,000$

$50,000-75,000$

3. Approxinate number of Missourl state govemment publications in

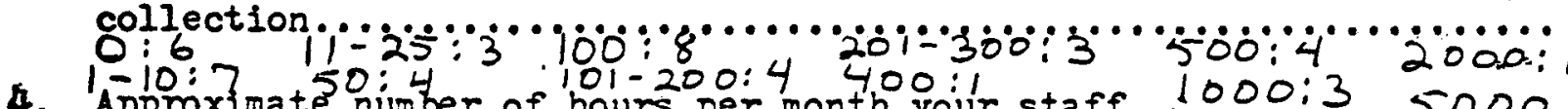

4. Approximate number of hours per month your staff 1000:3 5000:2 devotes to obtaining and processing Missouri state governnent publications.

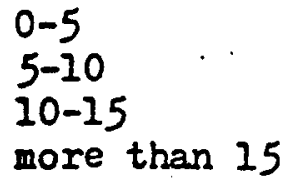

5. Approximate number of Missourl state government publications requested

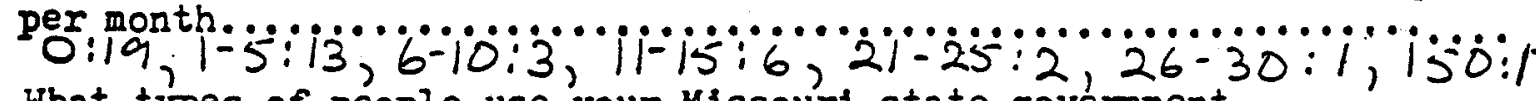

6. What types of people use your Missour1 state goverrment publications?

7. Are your needs for Missourl state government publications (General Public 
8. Does the present systen for bibliographic control of Missourl state government publications fill your needs............. Yes (28) No (22) ?(3)

9. If the answer to question eifht is no, would you please write your suggestions for improving the system on the back of this page. See below.

10. Are you able to obtain the infomation you need about Missouri state government operations and services................. Yes. (37) No (10). ?(2)

11. From which agencies do you have the best results in obtaining Missouri govemment publications? See attached.

12. With which agencies do you have the nost problem in obtaining Missouri government publications? See attached.

13. If during the past year you purchased any Missouri state government publications, approximately how much did you spend on then. $\$ 0-20.00$ $\$ 20.00-\$ 40.00$ $\$ 40.00-\$ 60.00$ $\$ 60.00-\$ 80.00$ $\$ 80.00-\$ 100.00$ more than $\$ 100.00$

14. Do you think that a depository for Missouri state government publications in your area would give you better service with these items than you now receive........................................... Yes (33) No (10) ?(2)

15. Are there organizations and patrons in your area which would support a Missouri depository library system? Please specify.

PLEASE SEND CONPLETED QUESTIONIAIRE TO: LUCY Rauch

Reference Defartient

Thomas Jefferson Iibrary System

214 Adans Street

Sitate Documents Depository System 2

Jefferson City, Missouri 65101

Central distribution from state Library 2

Cumulative bibliography 2

Free access to al1 documents printed by all state depts. or agencies 1 Index to State Documents 1

More comprehensive Monthly Checklist of State publications 3 uniform classification system of documents 2 
11. Best Agencies:

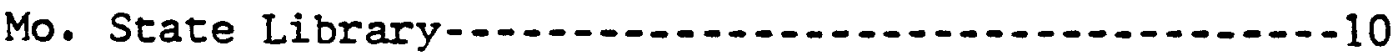
Secretary of State-1..

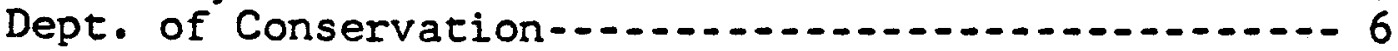
Mo. Tourism Commission-.......

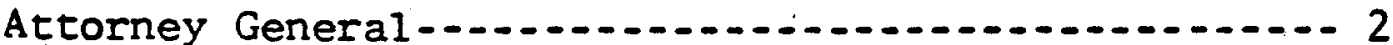
Auditor's Office-1. Dept. of public Health and Welfare-............... 2 Dept. of Secondary and Elementary Education-........ 2 Cooperative Extension Service-....................... 1. Dept. of Agriculture-......... Dept. of Employment Security-....................... 1 Dept. of Mental Health-_. Dept. of Natural Resources-....................... 1 Div. of Commerce and Industry-.................... 1 Geological Survey and Water Resaurces.............. 1 Governor's Office-. Highway Commission-........ Law Enforcement Assist, Council-.................... 1 Mo. Botanical Garden-1._. Mo. Extension Office-........... Municipal Reference Library-...................... 1 Resource and Development Commission-.............. 1

\section{2. "Worst"Agencies:}

Dept. of Revenue-................. 2

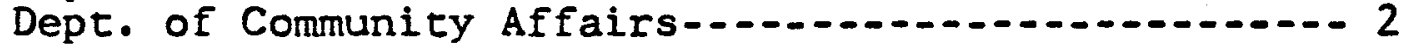
Governor's Office-..................................... 1 Mo. Legislature-1... Personnel Division-.................................... 1 State Planning-..-_. Workman's Compensation-............................ 1 
to establish a depository library system for Missouri state publications.

Section 1. As used in this act, the following words and terms mean:

(1) "State publications" includes all multiply-produced publications printed or purchased for distribution by the state, the legislature, constitutional officers, any state department, committee, or other state agency supported wholly or in part by state funds;

(2) "Print" includes all forms of printing and duplicating, regardless of format or purpose, with the exception of correspondence and interoffice memoranda;

(3) "State agency" includes every state office, officer, department, division, bureau, board, and commission, whether legislative, executive, or judicial, and any subdivisions of each, including state-supported institutions of higher education.

(4) "State department" includes the fourteen major administrative units of state government created by the state Reorganization Act of 1974.

(5) A depository is a designated place for collecting, maintaining, and making available to the general public publications issued by agencies of the Missouri state government.

Section $\hat{2}$. There is hereby createa within the Department of Higher Education, within the State Library, a Depository Library Center and a depository library system for the state of Missouri. The State Librarian shall appoint a Depository Librarian who shall administer a Missouri state publications collection and depository library system.

Section 3. Under the direction of the Coordinating Board for Higher Education, the State Library shail: (1) establish and administer, with the approval of the Coordinating Board, such rules and regulations as are required to carry out the provisions of this act; (2) develop and maintain standards for depository libraries, with the approval of the Coordinating Board; (3) designate depository libraries, in accordance with the provisions of this act; (4) advise state agencies annually of the number of copies of publications needed for distribution; (5) receive from state agencies on or about publication date the number of copies of each publication specified and distribute these to the depository libraries; (6) publish at least monthly and distribute to depository libraries, other Missouri public, college, and university libraries, legislators, state agencies, other state libraries, and to other libraries upon request, an official indexed list of.Missouri state publications with an annual cumulated index.

Section 4. Every state agency shall, upon release, deposit a sufficient number of copies of each of its state publications with the Depository Library Center to meet the needs of the depository library syster. The number of copies requized for the depository system shall 
be certified to each agency annually by the Depository Librarian. This requirement includes sale items, with the exception of the university presses, which shall be required to deposit 2 copies of each publication with the depository library center.

Section 5. After receipt of the state publications of any agency, the Depository Library Center shall distribute copies of such publications as follows: (1) Two copies to the state Archives for permanent preservation; (2) 10 copies to the State Historical Society; (3) two copies to the Library of Congress; (4) one copy to an additional national research library designated by the Depository Librarian; (5) one copy to each four-year state university campus library system which chooses to become a full or partial depository under section 8 (1) or 8 (2); (6) one copy to each full depository, as provided in Section 8 (1); (7) one copy to each partial depository which has elected to receive designated publications, as provided in section 8 (2). The Center shall retain sufficient copies in the Missouri state Library for preservation, reference, and interlibrary loan purposes and for distribution in accordance with any agreements entered into with other states for the exchange of state publications.

Section 6. Each state agency, each house of the General Assembly, and the Juaicial branch, shall designate a publications officcr, who shall be responsible for supplying the publications of that agency, to the Depository Library Center. Each agency shall notify the Depository Librarian of the identity of its publications officer within 30 days after the effective date of the law or upon change of personnel. The publications officer shall supply the Depository Center annually or upon request with a complete list of the department's current state publications.

Section 7. The Depository Library Center may enter into depository contracts with public libraries and college and university libraries which meet the standards for depository eligibility approved by the Coordinating Board for Higher Education. The standards shall include the following requirements: (1) ability of the library to receive, process, organize, retiin, and snake avaiiable state puoilicaticus; i2j willingness of the library to provide assistance and interlibrary loan service for depository publications; (3) such geographical distribution of libraries as will make publications conveniently accessibie to residents in all areas of the state.

Section 8. Depositories shall be of two types: (1) Full depositories shall receive all publications of all state agencies and shall maintain full collections of these publications for a minimum specified period. (2) Partial depositories shall be designated for the purpose of developing specialized collections of state publications in major subject areas. Partial depositories shall receive and maintain for a minimum specified period designated publications, as agreed to by the Depository Library Center. Partial despoitories shall be considered as supplementary to coverage of the state by full depositories. A partial depository shall meet the same standards for reference and interlibrary loan services as a full depository.

Section 9. This act shall not affect the general public distribution of publications hy state departments, nor shall it affect the distribution of publications by the Secretary of State under RsMo 2.091 and 3.130, except that each agency shall deposit the requested number of copies of each publication with the Depository Library Center. 
Library name:

Library address:

We are definitely interested in becoming a Missouri State Documents Depository

We, would be willing to serve if our geographical area needs a location. We think the following library in our area would be better suited to becoming a depository:

If interested in becoming a depository yourself, would you prefer to be a:

full depository

partial depository (Please indicate areas of interest)

Name of person who would probably be in charge:

We currently maintain a Missouri Documents collection.

If so, how do you presently classify your lilissouri documents?

You would plan to continue the current system.

You would think now would be a good time to reconsider your classification.

\section{PLEASE RETURN TO:}

Eddie Altis, Chaiman

State Documents Depository Legisiation Subcomittee

- c/o Southwest hissouri State University Library

Springfieid, Mo. 65801 
DEFINITELY INTERESTED ( fUIl) (7)

Nevada Public (Nevada)

Jefferson College (Hillsboro)

SMSU (Springfield)

Kent Library (SMSU-Cape)

St. Louis County?

Picklar Memorial (NMSU-Kirksville)

St. Louis Public.

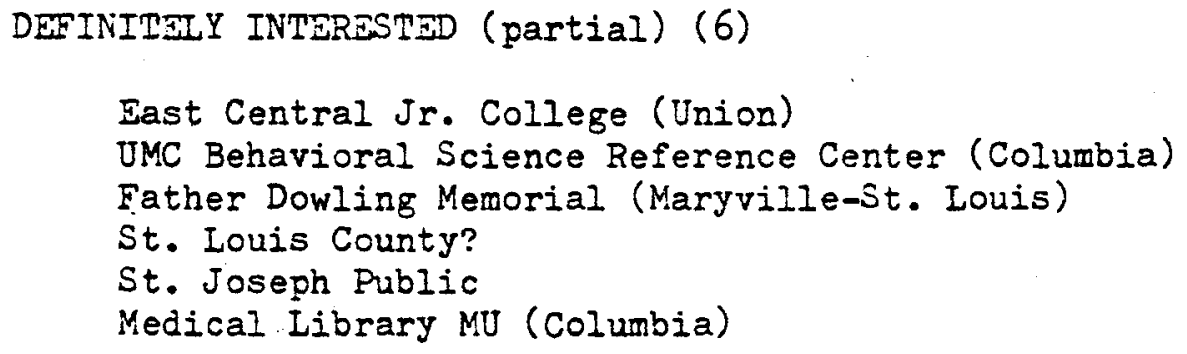

WOULD BE WIIIING TO SERVE GDOGRAPHICAL AREA (5)

Sedalia Public (Sedalia)

Town \& Country Regional (Neosho)

George M. Smiley Memorial (Central Methodist-Fayette)

Missouri Southern (Joplin)

Current River Regional (Van Buren)

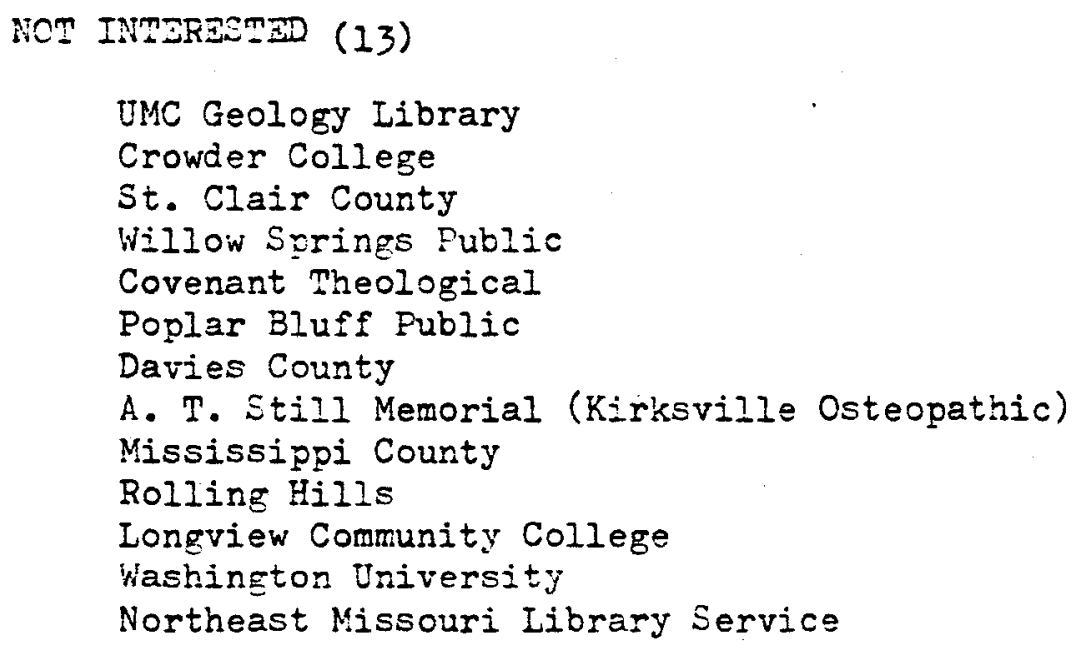




\section{SECOND REGULLAR SESSION \\ HOUSE BILL NO. 1172}

78TH GENERAL ASSEMBLY

INTRODUCED BY REPRESENTATIVE GOODE.

Pre-filed December 1, 1975, and 800 copies ordered printed.

AGNES MOORE, Chiet Clerk.

1877

\section{AN ACT}

To establish and maintain a depository library system for publications of Missouri state agencies.

Be it enacted by the General Assembly of the State of Missouri. as follows:

Section 1. As used in this act, the following words and terms 2. mean and include:

3 (1) "State publications", all multiply-produced publications 4 printed or purchased for distribution by the state, the legislature, 5 constitutional officers. any state department, committee, or other 6 state agency supported wholly or in part by state funds:

7 (2) "Print", all forms of printing and duplicating, regardless of 8 format or purpose, with the exception of correspondence and 9 interoffice memoranda;

10 (3) "State agency", every state office, officer, department, 11 division. bureau, board. and commission, whether legislative. 12 executiven or judicial, and any subdivisions of each, including 13 state-supported institutions of higher education:

14 (4) "State department", the fourteen major administrative 15 units of state government created by the state reorganization act of 16 1974: 
(5) "Depository", designated place for collecting. main-

18 taining, and making available to the general public publications

19 issued by agencies of the Missouri state government.

Section 2. There is hereby created within the department of 2 higher education. within the state library. a depository library 3 center and a depository library system for the state of Missouri.

4 The state librarian shall appoint a depository librarian who shall

5 administer a Missouri state publications collection and depository 6 library system.

Section 3. Under the direction of the coordinating board for 2 higher education, the state library shall:

3 (1) Establish and administer, with the approval of the coor4 dinating board, the rules and regulations that are required to carry 5 out the provisions of this act:

6 (2) Develop and maintain standards for depository libraries. 7 with the approval of the coordinating board:

8 (3) Designate depository libraries, in accordance with the 9 provisions of this act;

10 (4) Advise state agencies annually of the number of copies of 11 publications needed for distribution;

(5) Receive from state agencies on or about publication date 13 the number of copies of each publication specified and distribute these to the depository libraries:

(6) Publish at least monthly and distribute to depository 16 libraries, other Missouri public, college and university libraries. 17 legislators, state agencies, other state libraries, and to other 18 libraries upon request, an official indexed list of Missouri state 19 publications with an annual cumulated index.

Section 4. Every state agency shall, upon release, deposit a 2 sufficient number of copies of each of its state publications with 3 the depository library center to meet the needs of the depository 4 library system. The number of copies required for the depository 5 system shall be certified to each agency annually by the depository 6 librarian. This requirement includes sale items. with the exception 
7 of the university presses, which shall be required to deposit two

8 copies of each publication with the depository library center.

Section 5. After receipt of the state publications of any agency.

2 the depository library center shall distribute copies of such

3 publications as follows:

4 (1) Two copies to the state archives for permanent preserva5 tion:

6 (2) Ten copies to the state historical society:

7 (3) Two copies to the Library of Congress;

8 (4) One copy to an additional national research library 9 designated by the depository librarian;

10 (5) One copy to each full depository, as provided in subdivi11 sion (1) of section 8;

12 (6) One copy to each partial depository which has elected to 13 receive designated publications, as provided in subdivision (2) of 14 section 8.

15 The center shall retain sufficient copies in the Missouri state 16 library for preservation, reference, and interlibrary loan purposes 17 and for distribution in accordance with any agreements entered 18 into with other states for the exchange of state publications.

Section 6. Each state agency, each house of the general 2 assembly, and the judicial branch of the state government shall 3 designate a publications office, who shall be responsible for 4 supplying the publications of that agency to the depository library 5 center. Each agency shall notify the depository librarian of the 6 identity of its publications officer within thirty days after the 7 effective date of this act and upon change of personnel. The 8 publications officer shall supply the depository center annually or 9 upon request with a complete list of the agency's current state 10 publications.

Section 7. The depository library center may enter into 2 depository contracts with public libraries and college and 3 university libraries which meet the standards for depository 4 eligibility approved by the coordinating board for higher educa- 
5 tion. The standards shall include the following requirements:

6 (1) Ability of the library to receive, process. organize. retain. 7 and make available state publications;

(2) Willingness of the library to provide assistance and 9 interlibrary loan service for depository publications:

10 (3) Such geographical distribution of libraries as will make 11 publications conveniently accessible to residents in all areas of 12 the state.

13 Any four-year university campus library system shall 14 automatically be designated as a full or partial depository. if it so 15 desires, provided it meets the eligibility requirements set forth 16 under subdivisions (1) and (2) of this section.

Section 8. Depositories shall be of two types:

2 (1) Full depositories shall receive all publications of all state 3 agencies and shall maintain full collections of these publications 4 for a minimum specified period.

5 (2) Partial depositories shall be designated for the purpose of 6 developing specialized collections of state publications in major 7 subject areas. Partial depositories shall receive and maintain for a 8 minimum specified period designated publications, as agreed to 9 by the depository library center.

10 Partial depositories shall be considered as supplementary to 11 coverage of the state by full depositories. A partial depository 12 shall meet the same standards for reference and interlibrary loan 13 services as a full depository.

Section 9. This act shall not affect the general public distribu2 tion of publications by state agencies except that each agency shall

3 deposit the requested number of copies of each publication with the 4 depository library center. 


\section{SECOND REGULAR SESSION \\ [PERFECTED] \\ HOUSE BILL NO. 1172}

78TH GENERAL ASSEMBLY

INTRODUCED BY REPRESENTATIVE GOODE.

Pre-filed December 1. 1975, and 800 copies ordered printed.

Read 1st time January 7, 1976.

Read 2nd time January 8,1976 , and referred to the Committee on Governmental Organization. January 13, 1976.

Reported from the Committee on Governmental Organization, February 17, 1976, with recommendation that the bill D. Pass and be placed on the Consent Calendar.

Bill ordered Perfected and printed, by Consent, February 25, 1976.

AGNES MOORE, Chief Clerk.

1877

\section{AN ACT}

To establish and maintain a depository library system for publications of Missouri state agencies.

Be it enacted by the General Assembly of the State of Missouri, as follows:

Section 1. As used in this act, the following words and terms

2 mean and include:

3 (1) "State publications", all multiply-produced publications

4 printed or purchased for distribution by the state, the legislature,

5 constitutional officers, any state department, committee, or other

6 state agency supported wholly or in part by state funds;

7 (2) "Print", all forms of printing and duplicating, regardless of

8 format or purpose. with the exception of correspondence and

9 interoffice memoranda;

10 (3) "State agency", every state office, officer, department,

11 division, bureau, board, and commission, whether legislative,

12 executive, or judicial, and any subdivisions of each, including

13 state-supported institutions of higher education; 
(4) "State department", the fourteen major administrative 15 units of state government created by the state reorganization act of 16 1974:

(5) "Depository", designated place for collecting, maintaining, and making available to the general public publications issued by agencies of the Missouri state government.

Section 2. There is hereby created within the department of 2 higher education, within the state library, a depository library 3 center and a depository library system for the state of Missouri. 4 The state librarian shall appoint a depository librarian who shall 5 administer a Missouri state publications collection and depository 6 library system.

Section 3. Under the direction of the coordinating board for 2 higher education, the state library shall:

(1) Establish and administer, with the approval of the coor4 dinating board, the rules and regulations that are required to carry 5 out the provisions of this act;

(2) Develop and maintain standards for depository libraries, with the approval of the coordinating board;

(3) Designate depository libraries, in accordance with the 9 provisions of this act;

(4) Advise state agencies annually of the number of copies of publications needed for distribution;

(5) Receive from state agencies on or about publication date the number of copies of each publication specified and distribute these to the depository libraries;

(6) Publish at least monthly and distribute to depository 16 libraries, other Missouri public, college and university libraries, 17 legislators, state agencies, other state libraries, and to other 18 libraries upon request, an official indexed list of Missouri state 19 publications with an annual cumulated index.

Section 4. Every state agency shall, upon release, deposit a 2 sufficient number of copies of each of its state publications with 3 the depository library center to meet the needs of the depository 
4 library system. The number of copies required for the depository

5 system shall be certified to each agency annually by the depository

6 librarian. This requirement includes sale items, with the exception

7 of the university presses, which shall be required to deposit two

8 copies of each publication with the depository library center.

Section 5. After receipt of the state publications of any agency.

2 the depository library center shall distribute copies of such

3 publications as follows:

4 (1) Two copies to the state archives for permanent preserva1 tion;

2 (2) Ten copies to the state historical society;

3 (3) Two copies to the Library of Congress;

4 (4) One copy to an additional national research library 5 designated by the depository librarian;

6 (5) One copy to each full depository, as provided in subdivi7 sion (1) of section 8;

8 (6) One copy to each partial depository which has elected to 9 receive designated publications, as provided in subdivision (2) of 10 section 8 .

11 The center shall retain sufficient copies in the Missouri state

12 library for preservation, reference, and interlibrary loan purposes

13 and for distribution in accordance with any agreements entered 14 in to with other states for the exchange of state publications.

Section 6. Each state agency, each house of the general 2 assembly, and the judicial branch of the state government shall 3 designate a publications office, who shall be responsible for 4 supplying the publications of that agency to the depository library 5 center. Each agency shall notify the depository librarian of the 6 identity of its publications officer within thirty days after the 7 effective date of this act and upon change of personnel. The 8 publications officer shall supply the depository center annually or 9 upon request with a complete list of the agency's current state 10 publications. 
Section 7. The depository library center may enter into depository contracts with public libraries and college and 3 university libraries which meet the standards for depository 4 eligibility approved by the coordinating board for higher educa5 tion. The standards shall include the following requirements:

(1) Ability of the library to receive, process, organize, retain, 7 and make available state publications;

(2) Willingness of the library to provide assistance and 9 interlibrary loan service for depository publications;

10 (3) Such geographical distribution of libraries as will make 11 publications conveniently accessible to residents in all areas of 12 the state.

13 Any four-year university campus library system shall 14 automatically be designated as a full or partial depository, if it so 15 desires, provided it meets the eligibility requirements set forth under subdivisions (1) and (2) of this section.

Section 8. Depositories shall be of two types:

2 (1) Full depositories shall receive all publications of all state 3 agencies and shall maintain full collections of these publications 4 for a minimum specified period.

(2) Partial depositories shall be designated for the purpose of 6 developing specialized collections of state publications in major 7 subject areas. Partial depositories shall receive and maintain for a 8 minimum specified period designated publications, as agreed to 9 by the depository library center. Partial depositories shall be 10 considered as supplementary to coverage of the state by full 11 depositories. A partial depository shall meet the same standards 12 for reference and interlibrary loan services as a full depository.

Section 9. This act shall not affect the general public distribu2 tion of publications by state agencies except that each agency shall 3 deposit the requested number of copies of each publication with the 4 depository library center. 
November 25, 1976

FISCAL NOTE NO. 1877

Purpose of Proposed Legislation:

The proposed legislation would make the publications of Missouri state government more easily and widely available and would insure preservation through a system of depository libraries.

Assumption:

This fiscal note assumes that the present services of the Missouri State Library and the participating depository libraries will provide a majority of the cost of this program. This fiscal note further assumes that a full-time library clerk n@\$5,436 and a half-time librarian II@ $\$ 10,044$ would be needed. This fiscal note also assumes that the annual mailing cost to 50 libraries would be $\$ 4,576$.

FY 1976-77 FY 1977-78

Estimated Cost:

Personal Service:

1Librarian@

$\$ 10,044$ (half-time)

1 Library Clerk II @

$\$ 5,436$

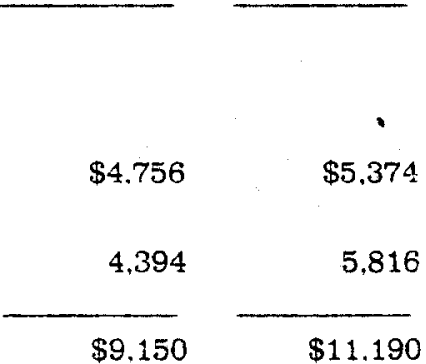

Equipment Purchase \& Repair:

2 Desks

$\$ 388$

2 Chairs

110

1 Typewriter table

1 Typist chair

1 Typewriter

Sorting bins 
H.B. 1172

Operation:

Postage

Mailing bags

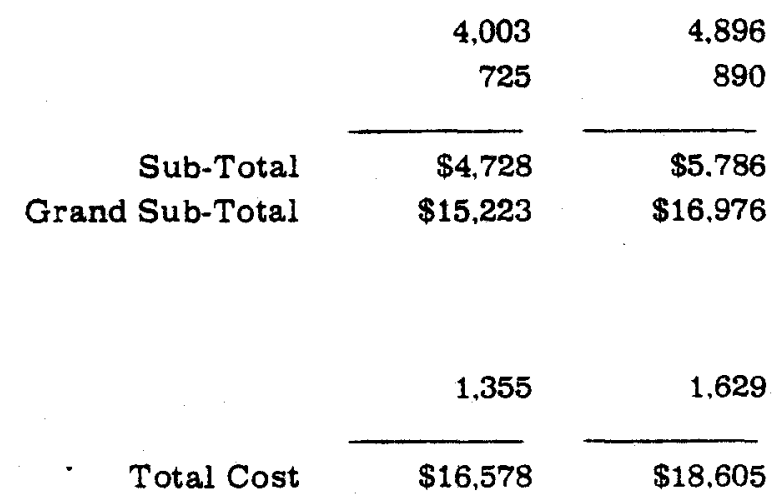

Source of Funds:

General Revenue Fund

$\$ 16,578$

$\$ 18,605$

Prepared by: Raymond J. Fountain

Approved by: John E. Hayes, Director,

Committee on State Fiscal Affairs 
SECOND REGULAR SESSION

SENATE COMMITTEE SUBSTITUTE FOR

\section{HOUSE BILL NO. 1172}

78TH GENERAL ASSEMBLY

Read 1st time April 7, 1976, and 1,000 copies ordered printed.

Reported from the Committee on State Departments with recommendation that the Senate Committee Substitute do pass.

VINITA E. RAMSEY, Secretary.

\section{A $\mathbf{N}$ ACT}

To provide for distribution of publications of Missouri State agencies.

Be it enacted by the General Assembly of the State of Missouri, as follows: Section 1. The state library shall, under the direction of

2 the coordinating board for higher education, publish monthly

3 an official indexed list of all printed publications of all state

4 offices, departments, divisions, boards and commissions,

5 whether legislative, executive or judicial, and any subdivisions

6 of each, including state-supported institutions of higher edu7 cation.

8 The library shall also distribute such numbers of copies

9 of such publications as it deems necessary to certain libraries,

10 also designated by it, which shall serve as depositories for mak-

11 ing available to the public such publications. No publications

12 shall be distributed to any libraries unless a request is made

13 therefor. 
Section 2. In addition to the distribution of the publica2 tions as aforesaid, the library shall distribute two copies of 3 each publication to the state archives for preservation and two 4 copies to the state historical society.

Section 3. The state library may enter into depository 2 agreements with public libraries and college and university li3 braries which meet standards for depository eligibility as ap4 proved by the state library.

March 17, 1976

FISCAL NOTE NO. 1877 (REVISED) FOR H. B. NO. 1172.

Purpose of Proposed Legislation:

The proposed legislation would make the publications of Missouri state government more easily and widely available and would insure preservation through a system of depository libraries.

Assumption :

This fiscal note assumes that the present services of the Missouri State Library and the participating depository libraries will provide a majority of the cost of this program. This fiscal note further assumes that a full-time library clerk II @ \$5,436 and a half-time librarian II (a) $\$ 10,044$ would be needed. This fiscal note also assumes that the annual mailing cost to 50 libraries would be $\$ 4 ; 576.5923$

FY 1976-77 FY 1977-78

Estimated Cost:

Personal Service:

1 Librarian@ $\$ 10,044$ (half-time)

1 Library Clerk II @ $\$ 5,436$

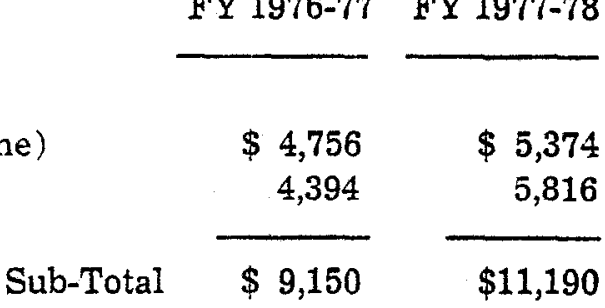

Equipment Purchase \& Repair :

2 Desks

$\$ 388$

2 Chairs

110

1 Typewriter table

1 Typist chair

1 Typewriter

Sorting bins 
FY 1976-77 FY 1977-78

Operation:

Postage

Mailing bags

\begin{tabular}{|c|c|c|}
\hline \multicolumn{2}{|c|}{ FY 1976-77 } & FY 1977-78 \\
\hline & 5,187 & 6,343 \\
\hline & 725 & 890 \\
\hline Sub-Total & $\$ 5,912$ & $\$ 7,233$ \\
\hline Sub-Total & $\$ 16,407$ & $\$ 18,423$ \\
\hline nt & 1,355 & 1,629 \\
\hline Total Cost & $\$ 17,762$ & $\$ 20,052$ \\
\hline & $\$ 17,762$ & $\$ 20,052$ \\
\hline
\end{tabular}

Source of Funds:

General Revenue Fund

Prepared by: Raymond J. Fountain

Approved by: John E. Hayes, Director,

Committee on State Fiscal Affairs

\section{$\checkmark$}




\title{
SECOND REGULAR SESSION \\ [TRULY AGREED TO AND FINALLY PASSED] HOUSE BILL NO. 1021
}

78TH GENERAL ASSEMBLY

\begin{abstract}
AN ACT
To repeal sections 182.140 and 182.291 , RSMo Supp. 1975, relating to public libraries in cities and counties, and to enact in lieu thereof seven new sections relating to the same subject.
\end{abstract}

Be it enacted by the General Assembly of the State of Missouri, as follows:

Section 1. Sections 182.140 and 182.291, RSMo Supp. 1975, are

2 repealed and seven new sections enacted in lieu thereof, to be

3 known as sections 182.140,182.291,2,3,4,5 and 6, to read as follows:

182.140. 1. Whenever qualified electors equal to five percent of

2 the total vote cast for governor at the last election in any city now

3 or hereafter containing more than four thousand and less than six

4 hundred thousand inhabitants petition the mayor, common

5 council or other proper governing body in writing asking that an

6 annual tax be levied for the establishment and maintenance of a

7 free public library in the city, and specify in their petition a rate of

8 taxation of not more than twenty-five cents for each one hundred

9 dollars of assessed valuation on all the taxable property in the ciry,

10 the governing body shall direct that the proposal be submitted to

11 the qualified voters of the city at a regular city election, at any

12 regular primary or general election at which voters of the city will

13 cast ballots, or at any election specially called to consider another

14 proposal or matter, but no special election shall be called solely for

15 the purpose of voting on the establishment and maintenance of a

16 free public library and the levy of a tax therefor. The proper

17 election officer shall give notice in the legal notice of the election at 
18 which the proposal is submitted, furnish ballots, poll books and

“Against a ........tax for each one hundred dollars assessed valuation for a public library".

If, from returns of the election, the majority of all the votes cast on the proposition at the election is "For a. . . . . . . tax for each one hundred dollars assessed valuation for a free public library", the governing body shall enter of record a brief recital of the returns and that there has been established a public library and thereafter the free public library shall be established, and shall be a body corporate, and known as such.

2. The tax specified in the notice, subject to the provisions of this section, shall be levied and collected, from year to year, in like manner with other general taxes of the city. The proceeds of the levy, together with all interest accruing on same, with library fines, collections, bequests and donations in money shall be deposited in the city treasury and shall be known as the "city library fund", and shall be kept separate and apart from other moneys of the city, and disbursed by the proper city finance officer only upon properly authenticated warrants of the city library board of trustees.

3. In case the proposed tax is sought as an increased tax for the maintenance of a free public library already established over a lesser tax rate theretofore voted and adopted, then such fact shall be recited in the petition and the notice of the election and the ballot 
52 shall submit to the voters the proposition.

53 "For a . . . . . tax increase over the present . . . . . . tax

54 for the public library",

55 or

56 "Against a ........tax increase over the present $57 \ldots \ldots \ldots \operatorname{tax}$ for the public library".

58 If a majority of all the votes cast on the proposition at the election

59 is for the tax submitted, the tax specified in the notice shall be

60 levied and collected in like manner with other general taxes of the

61 city, and shall be known as and become a part of the city library

62 fund and be administered as provided in section 182.200.

63 4. The tax may be reconsidered whenever the qualified voters

64 of the city determine by a majority vote given at any election held

65 therein at which the tax could originally have been submitted to

66 the qualified voters of the city under paragraph 1 of this section.

182.291. 1. After the establishment of a county library district

2 as provided in section 182.010, the board of trustees of any city

3 library within the county, which city has a population of more than

4 four thousand and a library tax levy equal to that levied for the

5 county library district, and which county library district has a

6 population of under two hundred and fifty thousand, with the prior

7 approval of the governing body of the city, may petition the county

8 court to permit the organization of a city-county library to provide

9 library service to the residents of the county by appropriate means

10 from the city library.

11 2. After the county library board has been appointed as 12 provided in section 182.050 , the county library board may petition 13 the county court to permit the organization of a city-county library 14 which shall provide library service to the residents of the county 15 by appropriate means from the city library. Within thirty days 16 after receiving the petition the county court shall notify the county 17 library board and the city library board of its decision by order of 18 record. If the petition is approved the city-county library shall be 19 deemed established; but if the petition is denied the parties may 
20 proceed as provided in sections 182.010 to 182.120 .

21 3. The city-county library shall be under the control and 22 supervision of a board of trustees of nine members. If the population of the county is larger than that of the city the county court shall appoint five members of the library board. If the population of the county is less than that of the city the county court shall appoint four members of the library board. If the population of the city is larger than that of the county the mayor of the city shall appoint five members to the library board. If the population of the city is less than that of the county the mayor shall appoint four members to the library board. The members shall serve a term of three years and until their successors are appointed and qualified in the same manner as their predecessors; except that the original members shall serve terms ranging from one to three years to be determined by the board at its first meeting. Immediately upon their appointment, the board shall organize as provided in section 182.060; and thereupon the city board shall cease to exist and shall turn over all property, books and records to the city-county board.

4. All unexpended funds of the preexisting separate city and county library districts shall be deposited by the custodians thereof with the city treasurer immediately upon the issuance of the county court approval of the petition.

5. For all tax purposes, including levies and adjustments thereof, the city library district shall become a part of the county library district at the beginning of the next fiscal year after the merger and the property within the city library district shall be treated as within the county library district for all such purposes; except, until the city library district shall become a part of the county library district the levy and collection of taxes shall be made as though no merger had taken place, so that the levy and collection of taxes shall be without interruption, and during that period no change in the levy shall take place. The funds collected shall be turned over to the city treasurer immediately upor collection. 
55 6. All of the real and personal property and all of the 56 obligations of the preexisting separate city and county library

57 districts shall, without further action, become the property and

58 obligations of the merged city-county library district, which shall

59 have an official name composed of the name of the city, followed by

60 the name of the county and followed by the words " county library 61 district".

62 7. The merged district, and the librarian, officials and board 63 thereof, shall have all of the rights, powers, responsibilities, and 64 privileges granted county library districts by the laws of the state 65 of Missouri and shall be governed by such laws, as though the 66 merged districts were a county library district, except:

67 (1) Where such laws are inconsistent with this section.

68 (2) The city treasurer shall be the custodian of all library 69 funds, which shall be deposited by the city treasurer, in a 70 depository selected and approved by the library board. The library

71 funds shall be kept separate and apart from other moneys of the 72 city and disbursed by the city treasurer only upon the proper 73 authenticated warrants of the library board. Such funds shall be 74 audited annually by the city in the same manner as other funds of 75 the city are audited.

76 (3) The library board shall prepare a budget for each fiscal 77 year and all expenditures shall conform to such budget. The budget 78 shall be prepared and approved by the library board and made 79 available to the members of the governing body of the city and the 80 members of the county court sixty days before the beginning of 81 each fiscal year, except the first budget of the merged district shall 82 be prepared forthwith and so delivered after the merger.

Section 2. As used in this act, "state publications" shall 2 include all multiple-produced publications of state agencies, 3 regardless of format or purpose, with the exception of cor4 respondence and interoffice memoranda.

Section 3. The state library shall, under the direction of the 2 coordinating board for higher education, publish monthly an 
3 official indexed list of all printed publications of all state offices, 4 departments, divisions, boards and commissions, whether

5 legislative, executive or judicial, and any subdivisions of each,

6 including state-supported institutions of higher education. The

7 library shall also distribute such numbers of copies of such

8 publications as it deems necessary to certain libraries, also

9 designated by it, which shall serve as depositories for making

10 available to the public such publications. No publications shall be

11 distributed to any libraries unless a request is made therefor.

Section 4. In addition to the distribution of the publications as

2 aforesaid, the library shall distribute two copies of each publica-

3 tion to the state archives for preservation and two copies to the

4 state historical society.

Section 5. The state library may enter into depository

2 agreements with public libraries and college and university

3 libraries which meet standards for depository eligibility as

4 approved by the state library.

Section 6. Every state agency, as enumerated in section 2,

2 shall, upon release, de posit with the state library sufficient copies

3 of each of its publications to meet the purposes of this act. 


\section{Chapter 181}

\section{STATE LIBRARY}

181.100. State publications defined.-As used in sections 181.100 to 181.140, and sections 182.140 and 182.291 , RSMo, "state publications" shall include all multiple-produced publications of state agencics, regardless of format or purpose, with the exception of correspondence and interollice memoranda. (L. 1976 H. B. 1021 2)

181.110. Publications of state officers, indexed list of to be published, distribution-depositories of publications, designation, request.-The state library shall, under the direction of the coordinating board for higher education, publish monthly an oflicial indexed list of all printed publications of all state oftices, departments, divisions, boards and commissions, whether legislative, executive or judicial, and any subdivisions of each, including state-supported institutions of higher education. The library shall also distribute such numbers of copies of such publications as it deems necessary to certain libraries, also designated by it, which shall serve as depositories for making available to the public such publications. No publications shall be distributed to any libraries unless a request is made therefor.

(L. 1976 H. B. 1021 3)
181.120. Library to distribute publications, to whom.-In addition to the distribution of the publications as aforesaid, the library shall distribute two copies of each publication to the state archives for preservation and two copies to the state historical society.

\section{(L. 1976 H. B. 1021 4)}

181.130. Depository agreements permitted, when.-The state library may enter into depository agreements with public libraries and college and university libraries which meet standards for depository eligibility as approved by the state library.

(L. 1976 H. B. 1021 \& 5)

181.140. State agencies to furnish copies of publications, to whom.-Every state agency, as enumerated in section 181.100 , shall, upon release, deposit with the state library sufficient copies of each of its publications to meet the purposes of sections 181.100 to 181.140 , and sections 182.140 and 182.291, RSMo.

(L. 1976 H. B. 1021 \& 6)

\section{from: Revised Statutes of Missour1, 1976 supplement}




\section{TITLE 6 - DEPARTMENT OF HIGHER EDUCATION \\ Division 20 - State Library \\ Chapter 2 - State Publications \\ Depository Library System}

\section{PROPOSED RULES}

\section{CSR 20-2.010 Standards for Depository Libraries}

PURPOSE: The State Library has the authority to designate public, college, and university libraries to act as depositories for state government publications. The State Library will distribute state publications on a regular basis to these libraries. This rule promotes free access. by all residents of the state to the publications by establishing minimum standards which libraries must meet to be eligible for depository status. It also gives the State Library power to enforce these standards.

(1) The State Library will select public, college, and university libraries to act as state publications depositories on the basis of geographic distribution, broadness of clientele served, and ability to meet the conditions specified in the following section.

(2) A depository library shall:

(A) Provide reference assistance in the use of state publications to any Mo. resident, Circulation of the publications is encouraged.

(B) Provide interlibrary loan service for state publications to any Mo, resident.

(C) Maintain sufficient hours of library service to allow convenient public access. State publications must be available for use during any hours the library is open.

(D) Inform the public frequently of the availability of state publications. The public includes the residents of the geographic area in which the library is located.

(E) Designate a professionally trained librarian to be responsible for service related to state publications, and provide adequate support staff. This librarian need not spend full time on state publications.

(F) Provide an orderly, systematic recording of receipt and subsequent arrangement of materials.

(G) Process and shelve all state publications within thirty (30) days of receipt.

(H) Provide space to house publications, with adequate provision for expansion.

(I) Dispose of publications only in accordance with policies established by the State Library. Depository publications remain the property of the State Library.

(3) The State Library shall enforce maintenance of these standards by inspections and annual surveys. A depository agreement may be terminated by the State Library for failure to comply with any of the conditions above or by a library at its own request.

Auth: section 181.021 RSMo (1969) and section 181.130 RSMo (Supp. 1976). 
6 CSR 20-2.020 Types of Depository Libraries

PURPOSE: Two types of depository library designations will be made in order to meet the varied needs of Mo. residents for state publications and to limit to a reasonable number the copies of publications to be requested from state agencies. This rule defines the types of depositories.

(1) Depository libraries shall be of two types:

(A) Full depositories shall receive all publications of all state agencies. The purpose of a full depository is to provide a complete research collection of state publications for the use of a major geographical area. The State Library will seek to designate at least one full depository in each of the following general areas of Missouri: northeast, northwest, southeast, southwest, central, St. Louis metropolitan area, Kansas City metropolitan area. Additional designations of full depositories may be made if justified by the needs of the residents of an area.

(B) Partial depositories will be designated to provide ready access to state government publications of broad general interest and to publications in subject areas needed by residents in particular areas of the state. A partial depository must receive a basic core of state publications to be specified by the State Library, and all the publications of at least one of the major departments of state government. Selection of the departments whose publications will be received in addition to the core collection will be made by the depository library.

Auth: section 181.021 RSMo (1969) and section 181.130 RSMo (Supp. 1976) .

NOTICE TO SUBMIT COMMENTS: Anyone may file a statement in support of or in opposition to tnese proposed rules at the Missouri State Library, Uepartment of Higher Education, 308 E. High St., P.O. Box 387, Jefferson City, Mo.65101, To be considered, comments must be received within 30 days after publication of this notice in the Missouri Register. No public hearing is scheduled. 


\section{Missouri Register}

\author{
Title 6-DEPARTMENT OF HIGHER \\ EDUCATION \\ Division 20-State Library \\ Chapter 2-State Publications Depository \\ Library System
}

\section{PROPOSED RULES}

\section{CSR 20-2.010 Types of Depository Libraries}

\begin{abstract}
PURPOSE: The State Library has the authority to designate public, college, and university libraries to act as depositories for state government publications. This rule defines the two types of depository designations which will be made in order to meet the caried needs of Missouri residents for state publications and to limit to a reasonable number the copies of publications to be requested from state agencies.
\end{abstract}

(1) Depository libraries shall be of two types:

(A) Full depositories shall receive all publications of all state agencies. The purpose of a full depository is to provide a complete research collection of state publications for the use of a major geographical area. The State Library will seek to designate at least one full depository in each of the following general areas of Missouri: northeast, northwest, southeast, southwest, central, St. Louis metropolitan area, Kansas City metropolitan area. Additional designations of full depositories may be made if justified by the needs of the residents of an area.

(B) Partial depositories will be designated to provide ready access to state government publications of broad general interest and to publications in subject areas needed by residents in particular areas of the state. A partial depository must.receive a basic core of state publications to be specified by the State Library. In addition, the State Library shall define categories of publications for selection by depository libraries. A category may be comprised of the publications of a department or division of state government or some other logical grouping of publications. Each partial depository library must select at least one category of publications to be received in addition to the core collection.

Auth: section 181.021 RSMo (1969) and section 181.130 RSMo (Supp. 1976)
6 CSR 20-2.020 Standards for Depository Libraries

PURPOSE: The State Libray uill distribute state publications on a regular basis to the libraries designated as depositories. This rule promotes free access to the publications by all residents of the state by establishing minimum standards which libraries must meet and maintain to be eligible for depository status. It also gives the State Library power to enforce these standards.

(1) The State Library will select public, college, and university libraries to act as state publications depositories on the basis of geographic distribution, broadness of clientele served, and ability to meet the conditions specified in the following section.

(2) A depository library shall:

(A) Provide reference assistance in the use of state publications to any Missouri resident. Circulation of the publications is encouraged.

(B) Provide interlibrary loan service for state publications to any Missouri resident.

(C) Maintain sufficient hours of library service to allow convenient public access. State publications must be available for use during any hours the library is open.

(D) Inform the public frequently of the availability of state publications. The public includes the residents of the geographic area in which the library is located.

(E) Designate a professionally trained librarian to be responsible for service related to state publications, and provide adequate support staff. This librarian need not spend full time on state publications.

(F) Provide an orderly, systematic recording of receipt and subsequent arrangement of materials.

(G) Process and shelve all state publications within thirty (30) days of receipt.

(H) Provide space to house publications, with adequate provision for expansion.

(I) Dispose of publications only in accordance with policies established by the State Library. Depository publications remain the property of the State Library.

(3) The State Library shall enforce maintenance of these standards by inspections and annual surveys. A depository agreement may be terminated by the. State Library for failure to comply with any of the conditions above or by a library at its own request. 


\section{APPLICATION FOR DESIGNATION \\ AS}

STATE PUBLICATIONS DEPOSITORY LIBRARY

Designation by the State Library of depository libraries for state publications is authorized by House Bill 1021 (78th General Assembly, 2nd Regular Session, effective August 13,1976 ), Sections 3 and 5.

In accordance with the provisions of House Bill 1021 ,

Library

hereby makes application for designation as a depository library for state publications.

TYPE OF DESIGNATION DESIRED (see attached description of Types of Depository Libraries ):

Full

Partial

STANDARDS FOR DEPOSITORY LIBRARIES, approved by the Coordinating Board for Higher Education September 13, 1976, provides that a library shall meet and maintain the following standards. Please place a check by each item to indicate your agreement to carry out the responsibility listed:

A depository library shall:

(A) Provide reference assistance in the use of state publications to any Mo. resident. Circulation of the publications is encouraged.

(B) Provide interlibrary loan service for state publications to any Mo. resident.

(C) Maintain sufficient hours of library service to allow convenient public access. State publications must be available for use during any hours the library is open.

List hours of service:

(D) Inform the public frequently of the availability of state publications. The public includes the residents of the geographic area in which the library is located.

(E) Designate a professionally trained librarian to be responsible for service related to state publications, and provide adequate support staff. This librarian need not spend full time on state publications.

Name of Librarian:

Title:

(F) Provide an orderly, systematic recording of receipt and subsequent arrangement of materials. 
(G) Process and shelve all state publications within thirty (30) days of receipt.

(H) Provide space to house publications with adequate provision for expansion.

(I) Dispose of publications only in accordance with policies established by the State Library. Depository publications remain the property of the State Library.

ORGANIZATION: How do you expect to handle depository documents?

Integrated into main collection Separate collection

Mixture. (describe:)

How. do you plan to classify depository documents?

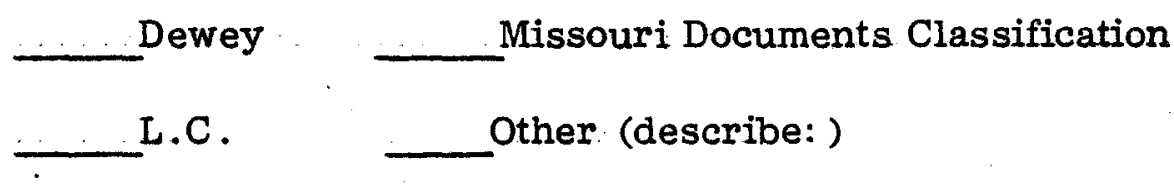

CQOPERATION: Has your library carried on any discussions with other libraries in your area as to which library/libraries should apply for full or partial depository status?
Yes
No
Not applicable (if yours is the only library in the area)

If so, what conclusions were reached?

AUTHORIZATION: Please attach photocopy of this application's authorization by policy-making body .

(Signature)

Title:

Address:

Date: 


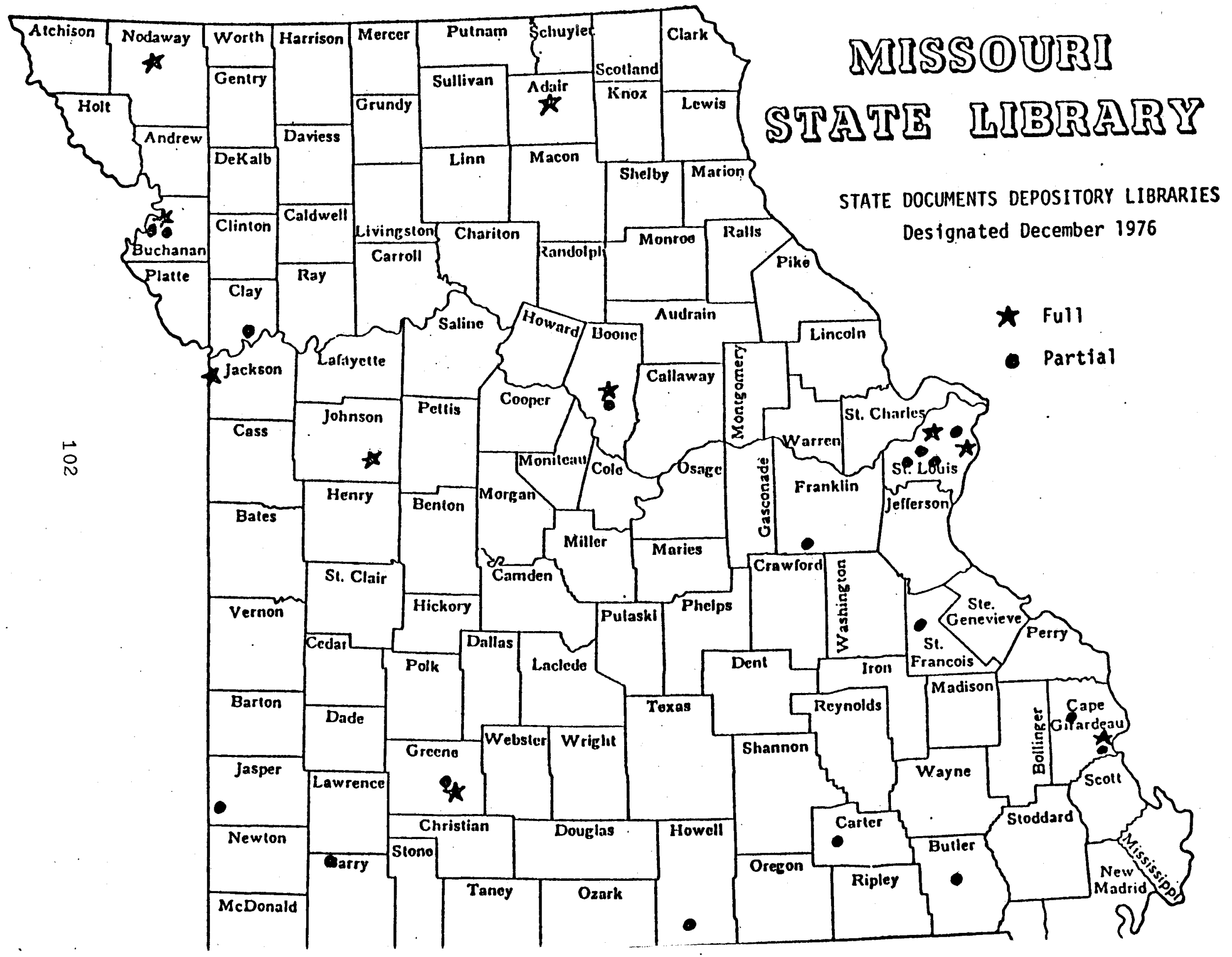


Northeast

Northeast Missouri State University, Kirksville

Northwest

Northwest Missouri State University, Maryville Missouri Western College, St. Joseph

Southeast

Southeast Missouri State University, Cape Girardeau

Southwest

Southwest Missouri State University, Springfield

Central

Central Missouri State University, Warrensburg University of Missouri - Columbia

Kansas City Metropolitan Area Kansas City Public Library

St. Louis Metropolitan Area

St. Louis Public Library

University of Missouri - St. Louis

STATUTORY DEPOSITORIES

Missouri State Library (Depository Center)

Missouri State Archives

Missouri State Historical Society 
Northeast

None

Northwest

St. Joseph Public Library

Rolling Hills Consolidated Library, St. Joseph

Southeast

Cape Girardeau Public Library

Riverside Regional Library, Jackson

Three Rivers Community College, Poplar Bluff

Southwest Current River Regional Library, Van Buren

Springfield-Greene County Library

Barry-Lawrence Regional Library, Monett

Missouri Southern State College, Jopl in

South Central

Southwest Missouri State University Residence Center, West Plains

Central

Daniel Boone Regional Library, Columbia

East-Central

Sullivan Public Library

Mineral Area College Instructional Resources Center, Flat River

Kansas City Hetropolitan Area

William Jewell College, Liberty

St. Louis Metropolitan Area

St. Louis County Library

Webster College Library

Maryville College Library

St. Louis University Law School Library 


\section{CORE DOCUMENTS}

$$
\text { January 1, } 1977
$$

State government publications designated as "core" documents will be distributed to all full and partial depository libraries. The purpose of the core collection is to provide a group of basic state publications which will answer many of the questions people have about state government and about Missouri in general. placing these publications in every depository will ensure accessibility throughout the state.

Documents were chosen for their value in helping citizens understand and gain access to their government, providing Missouri statistical or directory information or providing news on important subjects. Titles on the core list will be reviewed periodically for their usefulness. Librarians and state agencies are encouraged to suggest titles which they think should be added. When a new publication is instituted by a state agency, a determination will be made by the State Library. as to whether it should be added to the core list.

Publications not on the core list will be distributed to all full depositories and to some partial depositories, depending on the choices they make of categories of publications they wish to receive.

\section{OFFICE OF ADMINISTRATION}

Budget and Planning Division

Executive Budget (annual)

Mo. Economic Indicators (quarterly)

AGRICULTURE DEPT.

Crop \& Livestock Reporting Service

Mo. Farm Facts (annuai)

\section{AUDITOR}

Monthly Activity Summary (now mailed to all 235 public \& academic libraries.)

$$
\text { CONSUMER AFFAIRS, REGULATION \& LICENSING DEPT. }
$$

Mo. Consumer: Bi-weekly Article of Interest to Consumers.

Commerce \& Industrial Development Division

Mo. Directory of Manufacturing \& Mining (published annually by Information Data Co., St. Louis, through contractual agreement)

Mo. Corporate Planner (updated with inserts)

Finance Division

Biennial Report

Insurance Division

Annual Report \& Statistical Data

Savings \& Loan Supervision Division Biennial Report 


\section{ELEMENTARY \& SECONDARY EDUCATION DEPT.}

Report of the Public Schools of Missouri (annual)

Mo. School Laws (10oseleaf)

Mo. School Directory (annual)

GENERAL ASSEMBLY

Manual: List of Members, Officers, Committees, and the Rules of the House/Senate

Fiscal Affairs Comittee

Appropriations Summary (annual)

Legislative Research Committee

Revised Statutes of Missouri (every 10 yrs.)

Supplement to Revised Statutes (annual)

$$
\text { HIGHWAY DEPARTMENT }
$$

State Map

Accident Statistics

JUDICIAL DEPARTMENT

Annual Statistical Report: Judicial Conference

LABOR \& INDUSTRIAL RELATIONS DEPT.

Employment Security Division

Mo. State \& Area Labor Trade Trends (monthly)

Workmen's Compensation Division

Workmen's Compensation Laws (about every 5 yrs; updated annually by Jooseleaf sheets)

NATURAL RESOURCES DEPT.

Missouri's Environment (monthly)

PUBLIC SAFETY DEPT.

Fire Marshal

Annual Report

Highway Patrol

Mo. Traffic Crashes

REVENUE DEPT.

Tax Commission

Annual Report of the Proceedings \& Decisions of the State Tax Commission. 
Official Manual (biennial)

Roster of State, Dïstrict, \& County Officers (biennial)

Election Laws of the State of Missouri (frequent supplements)

Constitution of the State of Missouri

General Assembly Roster (biennial)

Session Laws (biennial)

Primary Election Returns (biennial)

Democratic \& Republican Convention Rosters (every 4 yrs.)

Democratic \& Republican State Committees and Slates of

Candidates (biennial)

Office of Chief Clerk

Certification of Candidates for Primary Election.

Certification of Candidates for General Election.

Administrative Rules Division

Mo. Register(monthly)

Code of Mo. Regulations (looseleaf)

SOCIAL SERVICES DEPT.

Family Services Division

Juvenile Court Statistics (annual)

Health Division

Mo. Vital Statistics (annual)

Mo. Hospital Directory (twice yearly)

Licensed Nursing Homes in Missouri (quarterly)

Licensed Ambulance Services

Licensed Boarding Houses in Missouri

Monthiy Vital Statistics

Probation \& Parole Division

Annua I Report

ALSO: Annual reports of the 14 major departments and 6 elected officials, if published.

Missouri statistical abstracts published by any agency. 


\section{SHIPPING LIST \# 1 \\ DATE Jan. 31, 1977 \\ PAGE $1 \quad O F \quad 2 \quad$ PAGES}

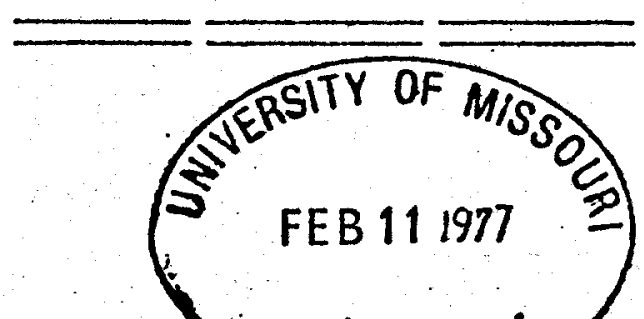

DOCUHENTS OIVISION

MISSOURI STATE LIBRARY 308 EAST HIGII STREET JEFFERSON CITY, MO 65101 (314) $751-3075$

CLASSIFICATION

MO

$A D$

2:R29

AGRICULTTURE DEPARTMENT

Crop \& Iivestock Reporting Service

2 Missouri Farm Facts - 1976. Annual.

GENERÄL ASSEMBLY

Joint Interim Comittee on Insurance

3. Shopping guide for automobile insurance. 1976. $12 \mathrm{p}$.

4t Shopping guide for homeowners insurance. 1976. $12 \mathrm{p}$.

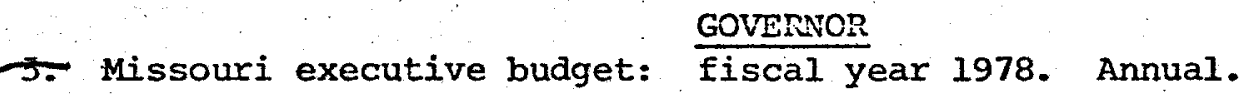

HIGHER EDUCATION DEPARTMENT

6- 1976 annual report to the Governor and members of the General Assembly.

HIGHWAY DEPARTMENT

7. Missouri official highway map: 1976. Annual.

IABOR \& INDUSTRIAL RELATIONS DEPARTMENT

- A. Annual report: fiscal year 1975.

T. Annual report: fiscal year 1976.

NATURAL RESOURCES DEPARTMENT

10. Second annual report, fiscal 1976, July 1, 1975-June 30, 1976.

11. Missouri's environment, vol. 3, no. 1, Jan. 1977.. Monthly.

SECRETARY OF STATE

Mo. procedures \& forms for filing in the office of the secretary of State \& the offices of recorders of deeds under Title 9 of the Uniform Commercial Code (Cover title: State of Missouri Uniform Commercial Code manual: procedures \& forms.) Rev. Jan. 1976. $63 \mathrm{p}$.

13. 1976 supplement: Constitution, state of Missouri 1945 (Revised 1974). 4. Corporation laws of the state of Missouri. Rev. 1975.

15. Mo. regisțer, Vol. 2, No. 1, Jan. 3, 1977. Monthly. (Mailed directly by printer.)

HI $1: 976$

\section{Mo}

AG.Cr

8: 976

(The remainder of class numbers are written in one line omitting "MO.")

GA. Ins 2:Au8

GA.Ins $2: H 75$

GOV $8: 978$

HIGH $3: H 53 / 976$

II $1: 975$

LI $1: 976$

NR $1: 976$

NR 10:3/1

SS $2: C 73 / 976$

SS $5: C 76 / 976$

SS $5: \mathrm{C} 81 / 975$

SS.Ad $10: 2 / 1$ 
SHIPPING LIST 1

DATE Jan. 31,1977

PAGE 2 OF

2. PAGES
DOCUIEENTS DIVISION MISSOURI STATE LIRRARY 308 EAST HIGH STREET JEFFERSON CITY, NO 65101 (314) $751-3075$

CLASSIFICATION

\section{SOCIAL SERVICES DEPARTMENT}

(Title of this edition: New horizons in corrections.)

Corrections Division

16. Annual report. (Title of $t$

Family Services Division

7. First annual report, fiscal years 1974-1975.

FULL \& STATUTORY (HISTORICAL) DEPOSITORIES ONLY:

\section{SECRETARY OF STATE}

10. 78th General Assembly, Journals of the House of the state of Missouri: :1976, Vol. II, Second Regular Session, Jan. 7, 1976 to May 15, 1976; Veto Session, Sept. 8, 1976 to Sept. 9, 1976. Annual.

19 78th General Assembly, Journal of the Senate of the State of Missouri: 1976, Vol. II, Second Regular Session, Jan. 7, 1976 to May 15, 1976;

Veto Session, Sept. 8, 1976 to Sept. 9, 1976. Annual.

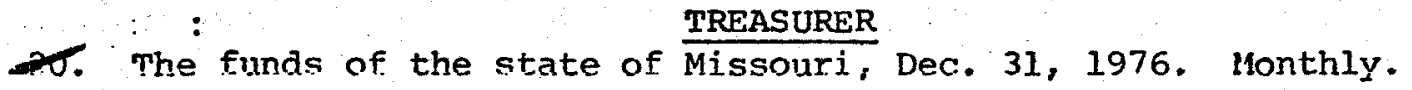

soc. $\operatorname{cor} 1: 974-75$

SOC.Fa $1: 974-75$

SS $11: 976 /$ HO

SS $11: 976 /$ Sen

TR $1.0: 976 / 12$ 
This agreoment made this: diay of .19

by and between the Missouri state I,ibrary (herein referred to as "the State Library") and the Elmer Ellis (University of Mo., Columbia) Library (herein referred to as "the Depository toibrary".)

WHEREAS, the General Asscmbly of the State of Missouri in 1976 enacted House Bill 1021, establishing a depository library system for the distribution of state publications,

WHEREAS, under that legislation the state Library may enter into depository agreenents with public libraries and colloge and university libraries; and

WHEREAS, Elmer Ellis (University of Mo., Columbia) Library has made application for Depository Library status and has been approved by the

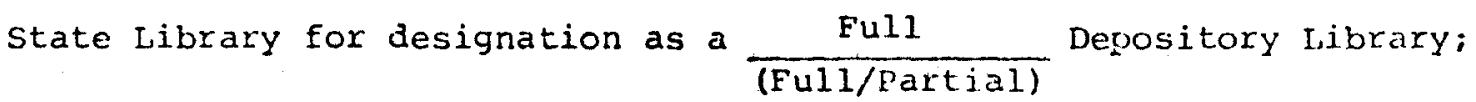

NOW THEREFORE, IT IS MUTUALLY AGREED TO AND UNDERSTOOD, that:

The state Library sha11:

(1) Mail state publications obtained under the provisions of house Bili 1021 in regular shipments to the Depository Library;

(2) Provide in each shipment a shipping list showing agency, title, and Missouri classification number for each publication;

(3) Provide assistance in the organization and reference use of Missouri state publications, as requested by the Depository Library;

(4) Publish monthly an official indexed list of state agency publications;

(5) Establish policies and procedures for the disposal of depository publications.

The Depository Library shall:

(1) Provide reference assistance in the use of state publications to any Missouri resident. Circulation of the publications is encouraged.

(2) Provide interlibrary loan service for state publications to any Missouri resident.

(3) Maintain sufficient hours of library service to allow convenient public access. State publications must be available for use during any hours the library is open.

(4) Inform the public frequently of the availability of state publications. The public includes the residents of the geographic area in which the libraxy is located. 
(5) Designate a professionally traincd librarian to be responsible for service related to state publications, and provide adequate support staff. This librarian need not spend full time on state publications.

(6) provide an orderly, systematic recording of receipt and subsequent arrangenent of materials.

(7) Process and shelve all state publicatjons within thirty (30) days of receipt.

(8) Provide space to house publications, with adequate provision for expansion.

(9) Dispose of publications only in accordance with policies established by the state Iibrary. Depository publications remain the property of the state Library.

The State Library shall enforce maintenance of the above Depository Library requirements by inspections and annual surveys. A depository agreement may be terminated by the state Library for failure to comply with any of the conditions above or by a Depository Library at its own recuest.

IN WITNESS WHEREOF, the state I,ibrary and the Depository Library have caused this agrement to be executed on the day, month, and year first above written by their duly authorized officers or representatives.

MISSOURI STATE LIBRARY

By: Charles O'Halloran

state Librarian

DEPOSITORY LIBRARY (PUBLIC LIBRARY)

or

DEPOSITORY LIBRARY (ACADEMIC LIBRARY)

By: Library Director

By: I,ibrary Director

By: Chairman, Board of Trustees

By: University or College President 


\section{DEPOSITORY SELECTION LIST \\ MISSOURI STATE GOVERNMENT DOCUMENTS \\ December 1979}

\section{OFFICE OF ADMINISTRATION}

AD-1 ACCOUNTING DIVISION.

Monthly financial summary, annual financial report; Chart of Accounts; several other regular reports.

AD-2 BUDGET \& PLANNING DIVISION.

All partial depositories have been receiving their publications; I would strongly recommend that libraries choose this category, as many valuable reports are issued.

AD-3 PERSONNEL DIVISION.

AD-4 REMAINDER OF OFFICE OF ADMINISTRATION.

Includes Central office of Administration publications, plus other divisions, which have not published much in the past (Purchasing, Design \& Construction, etc.).

\section{AGRICULTURE DEPARTMENT}

AG-1 CROP \& LIVESTOCK REPORTING DIVISION.

Many weekly, monthly and annual items, such as Crop \& Weather Report; Crop \& Livestock Reporter; reports on various crops \& types of livestock (Hogs \& Pigs; Hatchery Production, etc.). AG-2 REMAINDER OF AGRICULTURE DEPARTMENT.

Divisions of Plant Industries; Grain Inspection; Animal Health; Fairs; Weights \& Measures; Central Office.

\section{ATTORNEY GENERAL}

ATG-1 ATTORNEY GENERAL.

\section{AUDITOR}

AUD-1 AUDITOR.

All publications, chiefly audits of state agencies. (See our checklist for idea of quantity.). We do not anticipate requesting audits of local governmental units, such as school districts, city government, etc. These can be individually requested. 
CONSERVATION DEPARTMENT

CON-1 CONSERVATION DEPARTMENT - GENERAL.

Publications on hunting and fishing; wildlife; forestry; rare \& endangered species; hiking trails; etc.

CON-2 CONSERVATION DEPARTMENT - TECHNICAL.

Technical reports from Fisheries, Forestry, \& Wildlife Divisions.

CONSUMER AFFAIRS, REGULATION \& LICENSING DEPARTMENT

CARL-I STATE COUNCIL ON THE ARTS.

Occasional publications.

CARL-2 COMMERCE \& INDUSTRIAL DEVELOPMENT DIVISION and COMMUNITY DEVELOPMENT DIVISION.

Missouri Economic News; Missouri's New \& Expanding Manufacturers; Community Profiles (120 4-page fact sheets per year); studies on types of businesses and industries with potential for expansion in Missouri; public relations for industries to locate in Missouri.

CARL-3 FINANCE DIVISION.

Weekly bulletin; Quarterly Consolidated Report of Conditions of State Chartered Banks.

CARL-4 HUMAN RIGHTS COMMISSION.

Annual report; irregular pamphlets and handbooks about equal employment, fair housing, etc.

CARL-5 PUBLIC SERVICE COMMISSION.

Annual report; occasional brochures. CARL-6 PUBLIC SERVICE COMMISSION - REPORTS.

Reports \& Orders of the Commission (bound volumes covering a year or two.). Of limited interest.

CARL-7 PROFESSIONAL REGISTRATION DIVISION.

Directories of numerous licensing boards: Cosmetology; Dental; Healing Arts, etc.

CARL-8 TOURISM DIVISION.

Guide to Missouri vacations, camping, float fishing, etc. CARL-9 REMAINDER OF DEPARTMENT OF CARL.

Includes central office, Administrative Hearing Commission, Credit Unions Division, Environmental Improvement Authority, Housing Development Commission, Insurance Division, Public Counse1, Savings \& Loan Supervision Division. (None are prolific publishers.). 
ELEMENTARY \& SECONDARY EDUCATION DEPARTMENT

ED-1 ELEMENTARY \& SECONDARY EDUCATION DEPARTMENT.

A fairly big publisher.

\section{GENERAL ASSEMBLY}

GA-1 BILLS \& JOURNALS.

All versions of all bills introduced in Missouri House \& Senate (3000/session?); daily journals during session.

GA-2 REMAINDER OF GENERAL ASSEMBLY.

Occasional committee reports; publications of Fiscal Affairs Committee. (So far we have not received many General Assembly documents, but we hope to obtain more in the future.).

\section{GOVERNOR}

GOV-1 GOVERNOR.

Very few publications.

HIGHER EDUCATION DEPARTMENT

HI-1 HIGHER EDUCATION DEPARTMENT - CENTRAL OFFICE.

News letter; statistical reports; directories; plans.

HI-2 STATE HISTORICAL SOCIETY.

HI-3 STATE LIBRARY.

\section{HIGHWAY DEPARTMENT}

HIGH-1 HIGHWAY DEPARTMENT - GENERAL.

Status of Missouri Highways by Routes \& Systems; Traffic Trends On Missouri Highways; Bridge Records for Defense Requirements; Standard Specifications; brochures; other publications. (I have a feeling that much more is published in the Highway Department than we've ever seen. This category may need to be broken into parts later.).

HIGH-2 HIGHWAY DEPARTMENT - TECHNICAL.

Research reports on technical aspects of highway construction.

\section{JUDICIAL DEPARTMENT}

JUD-1 JUDICIAL DEPARTMENT.

Publications of State Court Administrator's Office; occasional publications from Supreme Court. (Does not include Court decisions, which are privately published.). 
LI-1 EMPLOYMENT SECURITY DIVISION.

Research reports on employment outlook, unemployment rates and insurance; characteristics of workers, etc.; brochures on unemployment insurance rules; brochures on job-hunting; others.

LI-2 REMAINDER OF LIR DEPARTMENT.

Includes Central Office of LIR Department; Workmen's Compensation Division; Mediation Board. Much less prolific than Employment Security Division.

\section{LIEUTENANT GOVERNOR}

LG-1 LIEUTENANT GOVERNOR.

News letters and reports on Ombudsman and Volunteer programs.

MENTAL HEALTH DEPARTMENT

MH-1 MENTAL HEALTH DEPARTMENT - CENTRAL OFFICE.

State plans, such as alcohol abuse and drug abuse; occasional pamphlets and reports; standards and guidelines.

MH-2 STATE MENTAL HEALTH INSTITUTIONS.

Newsletters, such as Focus (Higginsville State School and

Hospital), Show-Me-Too (St. Joseph State Hospital); etc.

\section{NATURAL RESOURCES DEPARTMENT}

NR-1 ENVIRONMENTAL QUALITY DIVISION.

Planning documents and reports on water quality, air quality, solid waste management.

NR-2 GEOLOGY \& LAND SURVEY DIVISION - GENERAL.

NR-2-A GEOLOGY \& LAND SURVEY DIVISION - TECHNICAL.

NR-3 REMAINDER OF NATURAL RESOURCES DEPARTMENT.

Brochures and reports of Central Office, Energy Agency,

Historic Preservation Office, Parks and Recreation Division.

\section{PUBLIC SAFETY DEPARTMENT}

PS-1 ADJUTANT GENERAL.

Includes newsletters and other publications of Diaster Planning Office, National Guard.

PS-2 CRIMINAL JUSTICE COUNCIL.

Newsletter, plans, program reports. 


$$
\left(\operatorname{Con}^{\prime} t\right)
$$

PS-3 HIGHWY PATROL.

Patrol News; research studies.

PS-4 REMAINDER OF PUBLIC SAFETY DEPARTMENT.

Publications of Central Office; Fire Marshal, Highway Safety

Division; Liquor Control Division; Water Safety Division.

\section{REVENUE DEPARTMENT}

REV-1 REVENUE DEPARTMENT.

Compilation of tax laws; Report of collections (monthly and

fiscal year); tax preparation guides.

PUBLIC SCHOOL RETIREMENT SYSTEM

SCH-1 PUBLIC SCHOOL RETIREMENT SYSTEM.

\section{SECRETARY OF STATE}

SS-1 SECRETARY OF STATE.

A11 publications not on Core List, including occational booklets explaining services; bound House \& Senate journals; instruction guides for election judges \& clerks; Corporation Laws; Securities Laws: Monthly Securities Bulletin; Uniform Commercial Code Manual; handbooks issued by Campaign Reporting, Securities, and other divisions.

\section{SOCIAL SERVICES DEPARTMENT}

SOC-1 CORRECTIONS DIVISION.

Horizon newsletter (weekly); monthly and annual statistical reports on commitments and releases; annual report; occasional reports and brochures.

SOC-2 FAMILY SERVICES DIVISION.

News letters; brochures and manuals on public assistance services; annual Title XX Social Services plan; occasional monographs.

SOC-3 HEALTH DIVISION.

Many brochures on sanitation, diseases, V.D., public health programs; reports of Center for Health Statistics; public health newsletter; publications and film lists.

SOC-4 SPECIAL SERVICES DIVISION.

Includes Aging Office; State Health Planning and Development Agency; Office of Economic Opportunity; Office of Manpower planning. In past, many reports on health manpower supply \& demand from health agency; few documents from others. 


$$
-6-
$$

SOCIAL SERVICES DEPARTMENT

$\left(\operatorname{Con}^{\prime} t\right)$

SOC-5 REMAINDER OF SOCIAL SERVICES DEPARTMENT.

Includes Central Office; Probation and Parole Board;

Veterans' Affairs Division.

TRANSPORTATION DEPARTMENT

TRA-1 TRANSPORTATION DEPARTMENT.

TREASURER

TR-1 TREASURER.

Funds of the State of Missouri (monthly).

LIBRARY

PERSON COMPLETING LIST

DATE 


\section{SELECTED BIBLIOGRAPHY}

\section{Record Files}

The author has assigned arbitrary numbers to each record file as an organizational aid. Footnotes reflect this organizational arrangement.

A. University of Missouri-Columbia Library, Documents Office, Columbia, Missouri. (Referred to as Schilling File 1)

B. Missouri State Library, State Documents Office, Jefferson City, Missouri. (20 files)

1. Depository Laws--Other States

2. Missouri Depository Law, 1972-75

3. Missouri Depository Law, January-May 1976

4. State Depository System, June-December 1976

5. Depository Bill: Drafts, 1974-75

6. Depository Law Appropriations Requests, 1976-77

7. Depository Interest Survey 1975

8. State Depository Applications

9. Depository Law Summaries

10. Depository Selection Surveys, June 1977

11. Depository Agreements

12. Application for Depository Status and Agreements, 1978

13. Depository Selection Revision - 1978

14. State Depository Law - Cost Figures

15. Depository Survey, 1978-79

16. Missouri Depository Law Correspondence to July 1976 
17. State Depository Work Shop, November 18, 1977

18. Depository Rules - Mo. Register

19. State Documents Advisory Committee, 1976--

20. MLA Documents Committee, 1972-73

II. Books and Articles

Atterberry, Meryl. "New in Documents." Show-Me Libraries 27 (June 1976): 9-10.

- State Agency Handbook. Jefferson City: Missouri State Library, 1977. MO HI.Li2: D66.

- "State Depository Documents Update." Show-Me Libraries 29 (October 1977): 20.

Bartholomew, Harland, and Hare, S. Herbert. Facts, Findings and Recommendations on State Planning for Missouri; A Report to the National Resources Board. Jefferson City: Missouri State Planning Board, 1935.

Journal of the House. Missouri 78th General Assembly, 2d sess. Jefferson City, 1976.

Journal of the Senate. Missouri 78th General Assembly, 2d sess. Jefferson City, 1976.

Missouri. Code of State Regulations: Annotated. Jefferson City: Secretary of State, 1977.

Missouri. 1976 Supplement to the Revised Statutes of the State of Missouri, 1969. Jefferson City: Committee on Legislative Research of the General Assembly, 1976.

"Missouri Politics." FOCUS/Midwest 11 (no. 68), [1976?] : 12.

Missouri Register. Jefferson City: Office of the Secretary of State, 1976-1977.

Missouri State Documents Classification: Post-Reorganization Agency Codes and Form Divisions. Jefferson City: Missouri State Library, 1977. MO HI.Li2: D65.

Missouri State Documents: Preliminary Guide for Depository Libraries. Jefferson City: Missouri State Library, 1977. MO HI.Li2: D44. 
Official Manual of the State of Missouri. Jefferson City: Secretary of State, 1975-1978.

Shaffer, Dallas Y. "State Document Legislation: Nebraska A Case Study." Government Publications Review 1 (Fal1 1973): 19-28.

"State Depository System Would Help Students." Briefcase 1 (April 8, 1976): 1

U.S. Library of Congress. Monthly Checklist of State Publications 60 (December 1969): [1]. 